Anna Trojanowska

Instytut Historii Nauki PAN

Warszawa

\title{
PRACOWNIA CHEMICZNO-ANALITYCZNA WARSZAWSKIEGO TOWARZYSTWA FARMACEUTYCZNEGO W LATACH 1897-1914 (W ŚWIETLE „WIADOMOŚCI FARMACEUTYCZNYCH”)
}

\author{
Chemical-analytical laboratory of the Warsaw Pharmaceutical Society \\ in the years 1897-1914
}

Chemical-analytical laboratory of the Warsaw Pharmaceutical Society was established in 1897. In the laboratory, chemical (i.a. into pharmaceuticals and foodstuffs, physiological analyses) and bacteriological research was conducted and also didactic classes were given. There were also attempts to take up scientific activities.

The purpose of this work is to present the Society's activities and people, who headed them and tried to counteract the growing problem of adulteration of pharmaceuticals and foodstuffs, as well as to develop the basis of pharmaceutical knowledge in the difficult time for this profession - at the turn of the $19^{\text {th }}$ and $20^{\text {th }}$ centuries - when in practice the knowledge gained during studies turned out insufficient.

Keywords: Laboratory, Pharmaceuticals Control, Foodstuffs Control, Warsaw Pharmaceutical Society, Michał Białobrzeski, Stanisław Weil

Słowa kluczowe: Laboratorium, kontrola farmaceutyczna, kontrola żywności, Warszawskie Towarzystwo Farmaceutyczne, Michał Białobrzeski, Stanisław Weil

Pomysł utworzenia laboratorium analitycznego, czyli Pracowni Chemiczno-analitycznej, przy Warszawskim Towarzystwie Farmaceutycznym (dalej WTF) rysował się od chwili powstania Towarzystwa (1872) i został zrealizowany dwadzieścia pięć lat później w 1897 r., o czym informowano na łamach „Wiadomości Farmaceutycznych”.

\footnotetext{
${ }^{1}$ Nowo otworzona Pracownia Chemiczno-analityczna przy Towarzystwie Farmaceutycznym w Warszawskie. „Wiadomości Farmaceutyczne” 1897, s. 474-475. Wprawdzie w broszurze Warszawskie Towarzystwo Farmaceutyczne oraz Instytucje Pokrewne i z inicjatywy T-wa powstałe w perspektywie 1859-1834. Warszawa 1934 (dodatek do WF) autorzy podają rok 1874
} 
Celem opracowania jest ukazanie działalności laboratorium WTF - przeprowadzonych w nim badań i funkcji dydaktycznej, a także osób, które kierowały laboratorium i starały się przeciwdziałać rosnącemu problemowi fałszowania leków i środków spożywczych, oraz rozwinąć naukowe podstawy aptekarskiej wiedzy w trudnym dla tej profesji okresie przełomu wieków XIX i XX, gdy wiedza zdobyta w toku nauczania w praktyce stawała się niewystarczająca. Do opracowania tego tematu wykorzystałam sprawozdania z posiedzeń ogólnych oraz z posiedzeń Komitetu WTF zamieszczane w badanym okresie w „Wiadomościach Farmaceutycznych” - organie WTF.

W drugiej połowie XIX w. rola aptek uległa wyraźnym zmianom. Apteki traciły charakter laboratoriów, w których przygotowywano leki oraz sprawdzano tożsamość i jakość surowców leczniczych. Wraz z rozwojem przemysłu chemicznego na rynku farmaceutycznym pojawiało się coraz więcej gotowych środków leczniczych - leków chemicznych i wieloskładnikowych preparatów. Jednocześnie ze względu na liczne zafałszowania tych środków istniała stała potrzeba ich kontrolowania. Większość aptek działających wówczas w Królestwie Polskim posiadała laboratoria, jednak nie były one przygotowane na badanie gotowych preparatów leczniczych, mających często złożony skład. Środki takie wymagały innych metod analitycznych, nieraz skomplikowanych, do badań potrzebna były specjalistyczna wiedza oraz sprzęt, który nie znajdował się na wyposażeniu większości aptek. Podobnie przedstawiała się kwestia badań z zakresu bakteriologii i chemii fizjologicznej, a także badań żywności, nierzadko fałszowanej i „poprawianej” w niedopuszczalny sposób. W Warszawie działało wprawdzie laboratorium przy Urzędzie Lekarskim, w którym wykonywano tego rodzaju badania, ale potrzeby były znacznie większe. WTF postanowiło zatem stworzyć wzorcowe laboratorium, w którym można by było przeprowadzać zarówno rutynowe analizy chemiczne, fizjologiczne i bakteriologiczne, wykonywane na zamówienie, jak też kontrolne analizy leków i żywności, a także prace zmierzające do poszerzenia aptekarskiej wiedzy, m.in. do wypracowania optymalnych metod otrzymywania wybranych preparatów leczniczych.

Innym celem, który przyświecał założycielom laboratorium WTF, było stworzenie miejsca, gdzie młodzież, a także już wyszkoleni aptekarze, mogliby uzupełnić swą wiedzę i umiejętności, poznać zagadnienia szybko rozwijającej się chemii leków i analizy środków spożywczych, której nie uczono w Cesarskim Uniwersytecie Warszawskim.

jako rok założenia Laboratorium (tamże, s. 56), jednak z dostępnych materiałów wynika, że w tym okresie istniał zalążek laboratorium w postaci pierwszych okazów zbioru preparatów chemicznych, a właściwe laboratorium otworzono w 1897 r. i wówczas „,...] wykonywało analizy rozpoznawcze, naukowe i funkcjonowało jako laboratorium analityczne dla uczącej się młodzieży[...]" (tamże s. 10). Autorzy broszury nie wspominają szczegółowo o działalności laboratorium przed I wojną światową. Zob. też Obchody 60-lecia istnienia Warszawskiego Towarzystwa farmaceutycznego. „Wiadomości Farmaceutyczne” 1933, s. 20 


\section{Organizacja laboratorium}

Zaczątkiem Pracowni Chemiczno-analitycznej był gabinet chemiczny wyposażony pierwotnie dzięki darom członków Towarzystwa i uzupełniany późniejszymi zakupami, na które stale zbierano fundusze. Już w 1874 r. na Wystawie Powszechnej w Wiedniu, z myślą o przyszłym laboratorium, zakupiono przyrządy do chemii analitycznej (za 500 rubli), a w następnym roku podobnego zakupu dokonano na wystawie w Paryżu (za 220 rubli). W ten sposób stopniowo gromadzono przyrządy laboratoryjne oraz tworzono zbiór preparatów i okazów chemiczno-farmaceutycznych (w 1912 r. zbiór zawierał 1558 okazów). Jednak dopiero przeniesienie siedziby Towarzystwa z ulicy Kanonia do nowego lokalu przy ulicy Długiej (Towarzystwo zajęło wówczas osiem pokoi na pierwszym piętrze budynku frontowego) umożliwiło urządzenie Pracowni Chemiczno-bakteriologicznej².

Według protokołu z posiedzenia ogólnego WTF otwarcie laboratorium nastąpiło 27 września $1897 \mathrm{roku}^{3}$. Wyposażenie pracowni chemicznej stanowiły wówczas:

[...] 4 stoły pokryte tafelkami kaflowymi, z szufladkami i szafkami, 2 stoły z kapami (wyciągami) do gazów trujących, stół z piecykiem do spalań organicznych, piecyk do ogrzewania przy wysokiej temperaturze rur szklanych zatopionych, komplety odczynników, biuret, suszarki, kąpiel piaskowa nowego systemu, pompki wodne do wytwarzania próżni, stolik z dmuchawą, wagi chemiczne, polaryzator Laurenta, wagi Westphala do oznaczania ciężaru gatunkowego, komplet areometrów i inne dodatkowe przyrządy pozwalające wszystkie prace z zakresu chemii rozbiorowej z łatwością i precyzją dokonać $[\ldots]^{4}$.

Pracownię bakteriologiczną wyposażono w mikroskop Zeissa (do 1000 x powiększający, z przyrządem do rysowania), komplet odczynników i płynów barwiących, centryfugę na 4 próbówki, sterylizator, termostat miedziany, suszarkę o ścianach azbestowych, zapas szkieł i drucików platynowych ${ }^{5}$.

Zakładano, że laboratorium będzie pełniło funkcję dydaktyczną oraz naukową. Działalność dydaktyczną ukierunkowano na szkolenie młodzieży farmaceutycznej, zaś prace o charakterze badawczym miały służyć rozwojowi aptekarskiej wiedzy, zwłaszcza poznaniu składu chemicznego surowców leczniczych, opracowaniu

\footnotetext{
${ }^{2}$ W. B or ejsza: Czterdziestolecie Warszawskiego Towarzystwa Farmaceutycznego. „Wiadomości Farmaceutyczne” 1912, s. 406-408 (Wincenty Borejsza pełnił wówczas funkcję sekretarza WTF). W 1876 r. Alfred Fabian z Nowego Dworu przekazał na rzecz laboratorium 100 preparatów chemicznych przygotowanych we własnej pracowni. Borejsza wymienił też innych darczyńców: Cejzika, W. Karpińskiego, Lilpopa, W. Manduka, J. Mrozowskiego, J. Różyckiego, Szteynera i Szperlinga.

${ }^{3}$ Siódme Ogólne posiedzenie Towarzystwa Farmaceutycznego Warszawskiego. „Wiadomości Farmaceutyczne" 1897, s. 446-448.

${ }^{4}$ Nowo otworzona pracownia....

${ }^{5}$ Tamże, por. W. B o r e j s za: Czterdziestolecie....
} 
nowych lub uproszczeniu istniejących już metod analitycznych. Z laboratorium mogli korzystać członkowie WTF oraz farmaceuci, którzy chcieli prowadzić własne prace badawcze czy doskonalić się $\mathrm{w}$ analizie ${ }^{6}$, a także studenci farmacji, chemii, osoby przygotowujące się do egzaminów uczniowskich lub na stopień prowizora. Jednocześnie laboratorium miało prowadzić działalność usługową - wykonywać analizy na bieżące potrzeby. 0 działalności laboratorium informowano zazwyczaj w krótkich corocznych sprawozdaniach. Większe prace badawcze przedstawiano na posiedzeniach ogólnych Towarzystwa, a omówienia wybranych badań drukowano na łamach „Wiadomości Farmaceutycznych"7

\section{Początki działalność}

Pierwszym kierownikiem laboratorium został mgr Michał Białobrzeski (1869$1931)^{8}$, jego kandydaturę zgłosił i gorąco popierał prof. Marceli Nencki, pod kierunkiem którego Białobrzeski pracował w Instytucie Eksperymentalnym Cesarskiej Wojskowo-Medycznej Akademii w St. Petersburgu i przygotował dysertację magisterską. Kandydatura została przyjęta i 1 lipca 1897 r. Białobrzeski rozpoczął pracę; pozostał na tym stanowisku do 1900 r. Jego pomocnikiem został farmaceuta Konrad Kulesza9 .

Białobrzeski nie ograniczał się do wykonywania zamówionych analiz, ale przeprowadził też kilka większych projektów, jednak badania usługowe, z których miało

${ }^{6} \mathrm{~W}$ ciągu 15 lat pod nadzorem kierownika pracowało kilkadziesiąt osób - głównie uczącej się młodzieży. Zob. W. B o re j s z a: Czterdziestolecie... Z myślą o pracach z zakresu analizy chemicznej w 1896 r. WTF wydało przekład podręcznika H. Be ku rs ta: Chemia analityczna dla aptekarzy.

${ }^{7}$ Szczegółową charakterystykę 25 lat działalności WTF zawiera przemówienie Henryka Huberta, zob. Protokół posiedzenia. Siódme Ogólne posiedzenie Towarzystwa farmaceutycznego Warszawskiego. „Wiadomości Farmaceutyczne” 1897, s. 450-474.

${ }^{8}$ Michał Białobrzeki (1869-1931) w 1890 r. zdał egzamin na pomocnika w Uniwersytecie św. Włodzimierza w Kijowie, praktykował w aptece Gajewskiego i Popowskiego w Odessie; studiował w Dorpacie, studia ukończył w 1894 r., uzyskując Złoty Medal im. księcia Suwarowa za rozprawę Rozbiór chemiczny Folia Bucco, a w szczególności Diosminy. Stopień magistra farmacji uzyskał w Cesarskiej Wojskowo-Medycznej Akademii w 1896; jako dysertację przedstawił pracę wykonaną pod kierunkiem prof. M. Nenckiego - Związek chemiczny heminy $i$ hematyny. W Petersburgu ukończył też kurs bakteriologii, następnie przeniósł się do Warszawy. Był także autorem prac: $O$ kondensacji difenolów z chlorkiem żelaza; $O$ jadzie rybim. Zob. Stypiński: Piq̨e ogólne posiedzenie Towarzystwa farmaceutycznego Warszawskiego. „Wiadomości Farmaceutyczne” 1897, s. 254-255, por. J. Br ze zi ń s ka: Rola Uniwersytetu w Dorpacie w kształceniu polskich studentów farmacji 1802-1918. Kołobrzeg 2017, s. 520, 524-525, 660-673, 816.

${ }^{9}$ Konrad Kulesza (1874-1938) studia farmaceutyczne ukończył w Warszawie, pracował jako chemik w laboratorium miejskim, zajmował też stanowisko asesora, po powrocie z Rosji, gdzie był więziony przez bolszewików, pracował jako aptekarz. Zob. Śp. Konrad Kulesza. „Wiadomości Farmaceutyczne" 1938, s. 703. 
utrzymywać się laboratorium, nie przynosiły wystarczających zysków - nie wystarczały na pokrycie wydatków, których sporą cześć pochłaniała pensja Białobrzeskiego $^{10}$. Kasa laboratorium świeciła pustkami, przez kilka miesięcy Białobrzeski wykonywał swoje obowiązki bezinteresownie, na początku 1900 r. zrezygnował jednak z kierowania laboratorium.

Po ustąpieniu Białobrzeskiego jego miejsce zajął prowizor farmacji Marian Stępowski (1867-1946), wcześniej związany z Kijowskim Towarzystwem Farmaceutycznym, który w 1899 r. w konkursie zorganizowanym przez WTF „dla pobudzenia ruchu umysłowego" otrzymał nagrodę za pracę: Podręcznik do badania i oznaczania wartości chemicznych i farmaceutycznych preparatów drogą analizy chemicznej, dla p. aptekarzy, drogistów i inspektorów lekarskich ${ }^{11}$. Stępowski prowadził laboratorium przez rok, ustąpił w 1901 r., a wtedy Towarzystwo zdecydowało się oddać laboratorium w dzierżawę. Na ogłoszenie o poszukiwaniu dzierżawcy zgłosił się chemik, Edward Koperski (wcześniej zajmujący stanowisku chemika w cukrowni). W umowie zawartej z Koperskim (na rok, licząc od 1 lipca 1901 r.) zaznaczono, że w laboratorium będą wykonywane wszelkiego rodzaju analizy oraz nadal będzie służyło kształceniu młodzieży w kierunku chemiczno-farmaceutycznym ${ }^{12}$. Wkrótce po objęciu przez niego stanowiska na łamach „Wiadomości Farmaceutycznych” ukazało się ogłoszenie, w którym wymieniono rodzaje usług świadczonych w laboratorium:

Pracownia chemiczno rozbiorowa przy WTF pod zarządem Edwarda Koperskiego wykonywa wszelkie rozbiory fizjologiczno-chemiczne, badania chemiczne i bakteriologiczne, produktów spożywczych, i technicznych, określa dobroć i czystość towarów i przetworów farmaceutycznych, dokonuje rozbiory ziemi i nawozów sztucznych,

${ }^{10}$ W sprawozdaniu za rok 1899, dotyczącym funduszy laboratorium, można wyczytać m.in., że dochody za analizy wynosiły 1003 rb., a za płyny mianowane $-246 \mathrm{rb}$. W tym czasie wydatki pochłonęły: uposażenie dyrektora Białobrzeskiego, które wynosiło 1200 rb. + $25 \%$ od przychodu (ok. 330 rb.), pomocnika Konrada Kuleszy - 250 rb. [nie podano za jaki okres], służącego - ok. 200 rb. (za 11 miesięcy); na odczynniki wydano - 275 rb., na gaz - 143 rb. Zob. [I.] Ha b el ski : Pracownia chemiczno-bakteriologiczna przy Warszawskim Towarzystwie Farmaceutycznym za rok 1899. „Wiadomości Farmaceutyczne” 1900, s.112-113.

${ }^{11}$ W. Bor ejs za: Czterdziestolecie.... s. 409-410. Marian Stępowski (1867-1946) początkowo studiował $\mathrm{w}$ Uniwersytecie Warszawskim, następnie podjął studia farmaceutyczne w Dorpacie, przez jakiś czas przebywał w Kijowie i jako członek Kijowskiego Towarzystwa Farmaceutycznego opublikował na łamach „Wiadomości Farmaceutyczne” szereg prac, m.in. obszerne Sprawozdanie z X Zjazdu Rosyjskich Przyrodników i Lekarzy w Kijowie (od 2 do 12 Września 1898 r.). „Wiadomości Farmaceutyczne” 1899, s. 17, 37, 56, 90, 120, 144, 171, 341; prace o kawie palonej i sposobie fałszowania tego artykułu (1898) oraz Notatki z wycieczki do Szwecji delegatów Kijowskiego Towarzystwa Farmaceutycznego (1899). s. 476-481. W 1901 r. wyjechał do Szwajcarii, gdzie w 1903 r. uzyskał stopień dr nauk przyrodniczych na Uniwersytecie w Bernie. Jego dalsze losy nie były związane z farmacją. Biogram Stępowskiego zamieściła J. B r z e zi ń s ka , dz. cyt. s. 517-520, 729-740; nie wspomina o jego działalności w Kijowskim Towarzystwie Farmaceutycznym.

${ }^{12}$ Z. Kł o b u s z e w s ki : Szóste Ogólne posiedzenie Warszawskiego Towarzystwa farmaceutycznego. „Wiadomości Farmaceutyczne” 1901, s. 335-336. 
a także przygotowuje płyny mianowane, odczynniki, roztwory barwników, itp. czynna 9-3 po południu' ${ }^{13}$.

Nie wiadomo jednak, jak w rzeczywistości Koperski wypełniał warunki umowy - nie informowano o tym w sprawozdaniach. Według późniejszej oceny jednego z członków WTF, Wincentego Borejszy, laboratorium utraciło wówczas charakter ogólny i stało się pracownią zajmującą się jedną tylko dziedziną wiedzy [?] ${ }^{14}$.

\section{Okres przestoju (1902-1909)}

Po wygaśnięciu umowy z Koperskim w 1902 r., pomimo wysiłków ze strony Towarzystwa by wznowić działalność laboratorium, nastąpił okres przestoju. Jak wynika ze Sprawozdania z 1902 r., znalezienie dzierżawcy nie było łatwą sprawą, zwłaszcza że Towarzystwo zamierzało zachować naukowo-praktyczny charakter laboratorium, aby swoimi pracami wyrobić sobie właściwą pozycję, zyskać zaufanie farmaceutów i ogółu ${ }^{15}$.

W „Wiadomości Farmaceutycznych” ukazywały się ogłoszenia o pracowni do wynajęcia:

Pracownia Chemiczno-Rozbiorowa odpowiednio ze wszystkimi przyrządami przy

Warszawskim Towarzystwie Farmaceutycznym urządzona, jest w każdym czasie na

dogodnych warunkach do wydzierżawienia. Lokal wygodny i widny. Pierwszeństwo

mają farmaceuci-chemicy. Kandydaci raczą się zgłaszać do apteki H. Biertümpfel,

Marszałkowska 136 w godzinach rannych ${ }^{16}$.

Laboratorium miało być dostępne dla każdego farmaceuty, który chciał pracować naukowo, a do obowiązków przyszłego dzierżawcy należało przyjmowanie farmaceutów zamierzających zdobywać wiedzę w zakresu chemii analitycznej (za wynagrodzeniem) ${ }^{17}$. Jak się wydaje, te wymagania odstraszały potencjalnych dzierżawców.

W okresie przestoju pracownie nie stały jednak zamknięte. W tym czasie Aleksander Bekker - asystent przy katedrze farmacji i farmakognozji Uniwersytetu

${ }^{13}$ Pracownia chemiczno... [ogłoszenie] „Wiadomości Farmaceutyczne” 1901 nr 20, s. nienumerowana.

${ }^{14}$ W. B orejs za: Czterdziestolecie...

${ }^{15} \mathrm{H}$. B i e r tü m p fe l, J. F. Ku ś m i e r s ki : Jeszcze kilka słów w sprawie pracowni chemiczno-rozbiorowej. „Wiadomości Farmaceutyczne” 1902, s. 431-432.

${ }^{16}$ Zob. „Wiadomości Farmaceutyczne” 1904 nr 12 i 14, s. nienumerowane

${ }^{17}$ Tamże. Zainteresowany dzierżawą był p. Lewenberg - chemik technolog. Do podpisania umowy jednak nie doszło (strony nie porozumiały się w sprawie warunków wcześniejszego wymówienia dzierżawy). Zob. [Z.] Kł o b u s z e w s ki : Szóste Ogólne posiedzenie Warszawskiego Towarzystwa Farmaceutycznego. „Wiadomości Farmaceutyczne” 1902, s. 288-290; tenże Siódme Ogólne posiedzenie Warszawskiego Towarzystwa Farmaceutycznego. „Wiadomości Farmaceutyczne" 1902, s. 410-411. 
Warszawskiego, zorganizował w lokalu WTF (korzystając z okazów farmakognostycznych i laboratorium) wykłady dla uczniów aptekarskich przystępujących do egzaminów pomocnikowskich. Prowadził je przez trzy lata ${ }^{18}$. Następnie w $1906 \mathrm{r}$. WTF oddało bezinteresownie laboratorium na użytek Towarzystwa Kursów Naukowych, które zostało powołane do życia po zawieszeniu wykładów na Uniwersytecie Warszawskim. W Sprawozdaniu z działalności Warsz. Tow. Farmaceutycznego za rok 1907 odnotowano:

Zatwierdzenie umowy z Zarządem Towarzystwa Kursów Naukowych w sprawie bezpłatnego oddania po 1 lipca 1908 roku [? do 1 lipca 1908] Towarzystwu Kursów Naukowych laboratorium analitycznego, istniejącego przy Tow. z zadowoleniem zaznaczyć można dużą frekwencję osób uczących się w laboratorium. Miejsca, pomimo kilku zmian, wszystkie były zajęte; w ostatnim semestrze uczęszczało 88 osób, z farmaceutów żaden nie korzystał ${ }^{19}$.

W roku następnym z laboratorium korzystało 128 studentów ${ }^{20}$. Zajęcia odbywały się m.in. pod kierownictwem profesorów Tadeusz Miłobędzkiego i [?] Sosnowskiego $^{21}$. Umowę z Towarzystwem Kursów Naukowych przedłużono na następny rok - do 1 lipca 1909. Doszło wówczas do kolejnej zmiany. W sprawozdaniu z posiedzenia WTF poinformowano, że z powodu opuszczenia laboratorium przez Towarzystwo Kursów Naukowych inwentarz laboratoryjny został przekazany „koledze Weilowi jako dalszemu kierownikowi laboratorium"22.

${ }^{18}$ W Sprawozdaniu z czynności Warszawskiego Towarzystw Farmaceutycznego za rok 1903ci. „Wiadomości Farmaceutyczne” 1904, s. 37-67, poinformowano, że w lokalu Towarzystwa odbyły się kursy dla uczniów farmacji pod kierunkiem kol. Bekkera, z tego 30 uczniów przystąpiło do egzaminu na stopień pomocnika aptekarskiego (s. 38). W 1904 r. uczniów było więcej i 52 osoby przystąpiły do egzaminów. Zob. Sprawozdanie z czynności Warszawskiego Towarzystwa farmaceutycznego za rok 1904. „Wiadomości Farmaceutyczne” 1905, s. 43-44.

${ }^{19}$ Sprawozdanie z działalności warsz. Tow. Farmaceutycznego za rok 1907. „Wiadomości Farmaceutyczne" 1908, s. 2.

W roku szkolnym 1908/9 frekwencja osób uczęszczających na zajęcia laboratoryjne w semestrze pierwszym wynosiła - 56, w drugim - 41. Zob. Sprawozdanie z działalności warsz. Tow. Farmaceutycznego za rok 1909. „Wiadomości Farmaceutyczne” 1910, s. 21-23.

${ }^{20}$ W. B o r e j s z a : Czterdziestolecie... s. 409-410.

21 „Towarzystwo Kursów Naukowych [...] Korzystając z bezinteresownie ofiarowanego przez Tow. farm. laboratorium, zaopatrzywszy takowe w nowe urządzenia i przybory, rozpoczyna tamże zajęcia z chemii nieorganicznej, technicznej i preparatów, dając tym możliwości przyrodnikom, rolnikom, farmaceutom doskonalenia się $\mathrm{w}$ analizie pod kier pp. T. Miłobędzkiego, dra [J.] Bieleckiego i dra L. Elżanowskiego." Zob. Wiadomości bieżące. „Chemik Polski” 1907, s. 69.

${ }^{22}$ Szóste Ogólne posiedzenie Warszawskiego Towarzystwa Farmaceutycznego „Wiadomości Farmaceutyczne" 1909, s. 259-260 


\section{Pod kierownictwem Stanisława Weila}

Stanisław Weil (1875-1944) ${ }^{23} \mathrm{z}$ wykształcenia był farmaceutą i chemikiem, pełnił również funkcję redaktora „Wiadomości Farmaceutycznych”. Kierownictwo laboratorium objął 1 lipca 1909 r, i wydawało się wówczas, że laboratorium ponownie zacznie funkcjonować zgodnie ze swoim pierwotnym przeznaczeniem. Zapowiedziano też, że wykonywane w nim prace będą referowane na posiedzeniach WTF, a omówienia ważniejszych będą publikowane na łamach „Wiadomości Farmaceutycznych".

Weil starał się spełnić pokładane w nim nadzieje, rozpoczął działalność usługową i naukową, ale uważał, że laboratorium powinno skupić się na pracach badawczych służących wyjaśnieniu aktualnych spraw i problemów, z którymi stykali się aptekarze w praktyce. Prowadzone przez niego badania dotyczyły głównie analizy leków. Jednak fundusze, a raczej ich brak, rzutowały na działalność laboratorium i po raz kolejny doprowadziło to do kryzysu. W 1913 r. Weil zrezygnował ze stanowiska i sprawa dalszych losów laboratorium ponownie była dyskutowana na posiedzeniu Komitetu WTF.

Z powodu rezygnacji Weila laboratorium praktycznie przestało działać. WTF postanowiło wówczas zwrócić się do Urzędu Lekarskiego Warszawy z prośbą „o dozwolenie w razach wątpliwych dokonywania w Laboratorium Higienicznym przy Urzędzie Lekarskim analiz preparatów chemicznych i farmaceutycznych pochodzących z aptek warszawskich (za stosowną opłatą)"24. Nadal poszukiwano też osoby, która podjęłaby się prowadzenia laboratorium. Na to stanowisko zgłosił się chemik technolog, inżynier Stefan Torżewski. Jego kandydatura, mimo że nie zyskała pełnego poparcia (nie był farmaceutą), została przyjęta. Torżewski objął prowadzenie laboratorium, a kasa Towarzystwa miała pobierać od niego opłatę 10\% dochodu za należność $\mathrm{z}$ analiz. Laboratorium pozostawało jednak pod nadzorem Weila ${ }^{25}$. Wykonywano w nim podstawowe badania i prace usługowe; w sprawozdaniu z $1913 \mathrm{r}$.

${ }^{23}$ Stanisław Weil (1875-1944) - mgr farmacji Uniwersytetu Warszawskiego, dr filozofii chemii, późniejszy docent w Zakładzie Chemii Farmaceutycznej, prof. chemii farmaceutycznej UW. Referent, a później szef sekcji spraw farmaceutycznych przy Departamencie Spraw Wewnętrznych Tymczasowej Rady Stanu (1917), autor prac z chemii leków, wykładowca historii farmacji (1925-1939). Wykładowca tajnych studiów farmaceutycznych w okresie okupacji hitlerowskiej. Autor monografii i podręczników. Zob. Dzieje nauki farmaceutycznych w Polsce 1918-1978. Pod red. Z. Je r z ma n o ws ki ej i B. Kuźn i cki ej, Warszawa-Łódź 1986 s. 510; por. A. Dan ek: Leksykon farmacji, Warszawa 1990, s. 530. Członek Polskiej Spółki Wyrobów Chemicznych „Roche” i dyrektor fabryki tejże spółki w Warszawie - zob. T. Kikta: Przemysł farmaceutyczny w Polsce, Warszawa 1972, PZWL s. 293.

${ }^{24}$ Posiedzenie Komitetu warsz. Tow. Farmaceutycznego. „Wiadomości Farmaceutyczne” 1913, s. 131.

${ }^{25}$ Trzecie ogólne posiedzenie Warszawskiego Towarzystwa Farmaceutycznego. „Wiadomości Farmaceutyczne" 1913, s. 221-22. 
brakuje jednak szczegółowych informacji o przeprowadzonych badaniach. W $1914 \mathrm{r}$. laboratorium nadal prowadził Torżewski przy współudziale farmaceuty bakteriologa S. Aberbacha ${ }^{26}$.

\section{Fundusze}

Problem braku funduszy stale ograniczał działalność naukową laboratorium i prowadził do konfliktów z Komitetem WTF. W pierwotnym założeniu laboratorium miało utrzymywać się ze składek członków Towarzystwa, którzy zobowiązali się na ten cel płacić przez trzy lata zadeklarowane przez siebie kwoty ${ }^{27}$. Liczono także na dochody za wykonanie analiz, tych jednak z roku na rok było coraz mniej. W $1901 \mathrm{r}$. w relacji z Pierwszego Ogólnego posiedzenia WTF ówczesny sekretarz WTF Zdzisław Kłobuszewski odnotował wnioski dotyczące laboratorium analitycznego:

[...] jakkolwiek wykonane w nim prace w ciągu czteroletniej działalności, z punktu naukowego, były bez wątpienia poważne i zaszczyt Towarzystwu przynoszące; strona jednak praktyczna, dużo pozostawiała do życzenia. Tak prowadzona pracownia mogłaby istnieć tylko przy wielkich substytucjach, należy zwiększyć kierunek działania na więcej praktyczny i tym sposobem zainteresować szersze koło kolegów, a nawet ogół ${ }^{28}$.

Jednym ze sposobów upowszechnienia informacji o działalności laboratorium miało być ogłaszanie wyników badań artykułów spożywczych (bez podawania źródła pochodzenia tychże artykułów) nie tylko w „Wiadomościach Farmaceutycznych”, ale i w pismach codziennych - by ogół dowiedział się o pożytecznej działalności laboratorium. Praktyka ta mogła zaprocentować w przyszłości, jednak nie była rozwiązaniem bieżących problemów. Nie pomogły też apele o wpłaty na laboratorium skierowane do aptekarzy z prowincji ${ }^{29}$, kasa świeciła pustkami, za co częściowo obwiniano kierownika laboratorium, któremu zarzucano wydawanie środków zbyt lekką ręką. W sprawozdaniu odnotowano, że wynagrodzenie kierownika [Białobrzeskiego] oraz koszt odczynników i utrzymania lokalu, przekraczały przychód z analiz ${ }^{30}$.

${ }^{26} \mathrm{H}$. Bi ertü m p fel: Odezwa w sprawie Pracowni Chemiczno-rozbiorowej przy Warszawskim Towarzystwie Farmaceutycznym. „Wiadomości Farmaceutyczne” 1914, s. 273-275.

${ }^{27}$ Tamże. Już w 1882 r. na ten cel Michał Damski ofiarował 1000 rb., w 1895 W. Karpiński 2000 rb. Składki płacili członkowie rzeczywiści WTF - byli nimi właściciele aptek, dzierżawcy oraz zarządzający aptekami rządowymi, pozostali farmaceuci mogli być członkami honorowymi - od nich składki nie były pobierane.

${ }^{28}$ Z. Kło bus z ewski: Pierwsze Ogólne posiedzenie Warszawskiego Towarzystwa Farmaceutycznego. „Wiadomości Farmaceutyczne” 1901, s. 67-68.

${ }^{29}$ H. Biertümpfel, J. F. Kuśmi erski: Jeszcze kilka słów $w$ sprawie pracowni chemiczno-rozbiorowej. „Wiadomości Farmaceutyczne” 1902, s. 431-432. Pomoc zaoferowały tylko 4 osoby w tym jedna z Odessy. Szacowano, że na utrzymanie potrzeba ok 2 tyś. rb.

${ }^{30}$ Kontrowersje budziło też postępowanie Białobrzeskiego, który przedstawił do nagrody pracę swojego pomocnika Konrada Kuleszy (1874-1938). Praca nie spełniała warunków konkurs - ofiarodawca nagrody Wincenty Karpiński wyraźnie przeznaczył ją za pracę analitycz- 
Wydaje się jednak, że sytuacja była bardziej złożona, świadczy o tym tekst o wymownym tytule Wimię prawdy i dobra Towarzystwa naszego ${ }^{31}$ zamieszczony w 1901 r. na łamach „Wiadomości Farmaceutycznych”. Komitet WTF przedstawił w nim sytuację finansową laboratorium, zaznaczając, że w ciągu 3 lat istnienia, mimo specjalnych składek, Towarzystwo musiało dołożyć na działanie laboratorium 5400 rubli. Działalność naukowo-dydaktyczna nie przynosiła żadnych dochodów - gościnność ofiarowana słuchaczom uniwersytetów zagranicznych, specjalistom chemikom nie mającym własnego laboratorium, prowizorom farmacji uzupełniającym swoje wykształcenie, nie dawała zysku. Gdy skończył się trzyletni okres płacenia przez członków WTF zadeklarowanych składek na rzecz laboratorium, a konto WTF było obciążone innymi wydatkami, nie można było pozwolić sobie na dalsze dokładanie do laboratorium i wstrzymano zajęcia. Komitet, chcąc rozwiać wszelkie wątpliwości i domysły, poinformował również, że:

Zwalanie odpowiedzialności za wszystkie trudności, które spadły na korporację od chwili zaszłego nieporozumienia, jest rzeczą niezmiernie dogodną dla grupy, która umywszy ręce od pomocy i pracy dla Towarzystwa, usunęła się. ${ }^{32}$

O jakie nieporozumienie chodziło? Można dowiedzieć się z tekstu, który był reakcją na powyższą notatkę: Odpowiedź na artykuł zamieszczony w No 11 „Wiadomości farmaceutycznych” pod tytułem „W imię prawdy i dobra Towarzystwa”33. Autor, Wincenty Karpiński, przedstawił w nim istotę sporu. Według niego na jednym z posiedzeń WTF (26 stycznia 1900 r.) obrady przybrały dość ostry charakter, a nie chcąc dopuścić do gwałtownej wymiany zdań, przewodniczący (W. Karpiński) odebrał głos jednemu z członków Towarzystwa, Alfonsowi Bukowskiemu, ten obraził się i wyszedł, a potem przysłał obraźliwy list do Karpińskiego. W odpowiedzi na pismo Karpińskiego Bukowski przedstawił swoją wersję wydarzeń, które doprowadziły do nieporozumienia ${ }^{34}$. Spór dotyczył wyboru władz WTF z plenipotencji - za takim sposobem opowiadał się syn ówczesnego przewodniczącego, Franciszek Karpiński. Bukowski był odmiennego zdania, ale prezes (W. Karpiński) odebrał mu głos. Po tym incydencie Bukowski napisał list do W. Karpińskiego, list (można przypuszczać, że nie były to przeprosiny) otworzył syn, „[...] który sprawę prywatną, czysto osobistej

ną, tymczasem Kulesza dokonał syntezy dwudziestu sześciu związków chemicznych. Postanowiono poprosić Białobrzeskiego, aby wyjaśnił, na jakiej podstawie wyróżnił pracę Kuleszy. Białobrzeskiemu zarzucano też, że dokonał zakupu książek i przyrządów do pracowni bez uzgodnienia tego z Komitetem WTF. Z. Kł o b u s z e w s k i : Pierwsze Ogólne... s. 68.

${ }^{31}$ Komitet W.T.F.: W imię prawdy i dobra Towarzystwa naszego „Wiadomości Farmaceutyczne" 1901, s. 279-281.

${ }^{32}$ Tamże.

${ }^{33}$ Odpowiedź na artykuł zamieszczony w No 11 »Wiadomości Farmaceutycznych" pod tytułem »W imię prawdy i dobra Towarzystwa“ „Wiadomości Farmaceutyczne” 1901, s. 311-312.

${ }^{34}$ A. B uk ow s ki: [bez tytułu] „Wiadomości Farmaceutyczne” 1901, s. 312-313. 
natury postarał się przenieść na tory publiczne [...]. Gdyby list odebrał ojciec, pewnie takiej afery by nie było" - zauważył Bukowski.

Spór między Karpińskim a Bukowskim doprowadził do rozłamu w WTK, zwolennicy Karpińskiego (17 osób - prawie połowa członków rzeczywistych) wystąpili z Towarzystwa, a to pociągnęło za sobą utratę znacznej część funduszy pochodzących ze składek członkowskich. Mimo starań nowego prezesa Henryka Klawe, nie udało się załagodzić konfliktu. Do porozumienia doszło dopiero w 1905 r., gdy pogarszająca się sytuacja aptekarzy zjednoczyła właścicieli aptek. Większość „uciekinierów" powróciła wówczas do WTF.

W Sprawozdanie z czynności Warszawskiego Towarzystwa Farmaceutycznego za rok $1905^{35}$ poinformowano, że działalność Towarzystwa nie była tak płodna, jakby sobie tego życzono, gdyż inne sprawy zajmowały społeczeństwo - ruch wolnościowy, zmiana warunków pracy, kształcenie w języku ojczystym; z tych powodów praca instytucji musiała być ograniczona, ale wspólna organiczna praca zjednoczyła kolegów aptekarzy - do Towarzystwa ponownie zapisali się m.in. Antoni Freyer, Henryk Hubert senior i Henryk Hubert junior, Wincenty Karpiński, Franciszek Karpiński, Michał Mutniański, M. Stypiński, T. Surzycki, Ferdynand Więckowski, Władysław Żółtowski. Zapisali się też nowi członkowie ${ }^{36}$. Mimo powiększenia grona członków Towarzystwa, składki nie wystarczyły na pokrycie deficytu w kasie WTF. W 1910 r., gdy Weil objął kierownictwo laboratorium, uważał, że na rozwój laboratorium potrzebne są dodatkowe fundusze - co najmniej 10 tysięcy rubli rocznie; a to możliwe było tylko przy uzyskaniu poparcia i zainteresowania się tą sprawą przez ogół aptekarzy. Apelował więc o opodatkowanie się na ten cel każdej apteki oraz opodatkowanie dostawców ${ }^{37}$. Na jego apel nie było jednak odzewu.

Rok później Weil przy okazji sprawozdania z działalności laboratorium ponownie stwierdził, że ogół aptekarzy powinien zainteresować się działalnością laboratorium i zmusić składy apteczne (pełniące funkcję hurtowni) do badania w nim oferowanych przez siebie środków leczniczych - dzięki temu laboratorium WTF pozyskałoby stałych klientów. Uważał też, że powinno się nakłonić większe firmy handlujące towarami aptecznymi do wnoszenia stałych składek na rzecz laboratorium ${ }^{38}$.

${ }^{35}$ Sprawozdanie z czynności Warszawskiego Towarzystwa Farmaceutycznego za rok 1905. „Wiadomości Farmaceutyczne” 1906, s. 3-5.

${ }^{36}$ Tamże. W sumie Towarzystwo miało 73 członków rzeczywistych, 60 honorowych, 38 honoris causa. Składki płacili członkowie rzeczywiści.

${ }^{37}$ S. We il: Nasze zadania. „Wiadomości Farmaceutyczne” 1910 s. 171. Weil szacował, że potrzeba 5-10 rubli rocznie od każdej apteki i składu. (W tym okresie w Królestwie Polskim było ok. 500 aptek).

${ }^{38}$ Szóste ogólne posiedzenie Warsz. Tow. Farmaceutycznego. „Wiadomości Farmaceutyczne” 1911, s. 405-408 [tu 406]. W tej sprawie zabrał również glos Herman Biertümpfel, jego zdaniem zbyt powolne napływanie składek na fundusz żelazny dla laboratorium, może spowodować zakłócenia w pracy, a to zniechęci interesantów, którzy muszą być należycie i w każdej chwili obsłużeni, bez czego laboratorium nie może się rozwijać. Tamże. 
Na ten temat wypowiedział się także inny członek WTF, Bronisław Koskowski, który widział sprawę finansowania laboratorium nieco odmiennie. Uważał mianowicie, że WTF przede wszystkim powinno starać się o jak najszerszy rozwój laboratorium i jednocześnie, publikując artykuły w prasie, zaprezentować swoją działalność społeczeństwu i środowisku aptekarskiemu, by zyskać uznanie i poparcie dla swojej działalności. Komitet WTF nie poparł wniosku Weila o dodatkowe fundusze na laboratorium - dopóki nie będzie ono działało normalnie. Być może sprawa funduszy przesądziła o dalszym losie laboratorium ${ }^{39}$.

W 1913 r. Weil, składając rezygnację ze stanowiska kierownika, zauważył, że laboratorium nie powinno mieć charakteru zarobkowego i wyłącznie analitycznego. Jego zdaniem, należy prowadzić w nim prace czysto naukowe, których rezultaty stałyby się przyczynkiem do rozwoju nauk farmaceutycznych ${ }^{40}$. Nie powinno kłaść się nacisku na rutynowe prace analityczne, lecz na badania dążące do rozwikłania niewyjaśnionych punktów w naukach związanych z farmacją, bądź też prace nad syntezami i badaniem nowych leków. Z tą myślą Weil podjął się przed kilku laty kierowania pracownią chemiczną, miał nadzieję, że poparcie ze strony ogółu farmaceutów dostarczy znacznej ilości analiz i prac płatnych, co umożliwi mu zajęcie się wyłącznie pracownią bez potrzeby szukania innych zajęć zarobkowych. Liczył na to, że będzie miał możność pracy czysto badawczej, rozwijającej i pogłębiającej nauki farmaceutyczne. Niestety poparcie ze strony farmaceutów było słabe, a analiz bardzo niewiele, dochód pracowni nie wystarczył nawet na pokrycie kosztu odczynników i szkła, nie mówiąc już o wynagrodzeniu za pracę - w tych warunkach badania naukowe prowadzone były tylko sporadycznie.

Weil uważał, że jeśli pracownia ma pełnić funkcje naukowe, należy albo dostarczyć jej więcej analiz potrzebnych do utrzymania się (np. żądać od dostawców certyfikatów wystawionych przez laboratorium WTF o jakości sprzedawanych towarów), albo zebrać kapitał żelazny (ok. 200 tysięcy rubli), aby odsetki pokryły wydatki pracowni i utrzymania pracowników ${ }^{41}$. Z tym pomysłem Weil wystąpił także podczas Pierwszego Zjazdu Aptekarzy Królestwa Polskiego w Łodzi (25-26 maja 1912 r.), na którym wygłosił referat: Stopniowe przekształcanie współczesnej apteki na instytucję więcej naukową. Jednym z jego wniosków było zorganizowanie przy aptekach pracowni analitycznych zajmujących się diagnostyką lekarską, badaniami środków spożywczych i kontrolą leków. Uważał, że taka działalność będzie opłacalna tylko wówczas, gdy aptekarze, prowadząc popularne odczyty, przekonają społeczeństwo o potrzebie stałego badania środków spożywczych ${ }^{42}$.

39 Tamże, s. 408.

${ }^{40}$ [S. We i l]: Sprawozdanie z czynności laboratorium chem. warsz. Tow. Farm. „Wiadomości Farmaceutyczne" 1913, s. 142-44. Autorem sprawozdania był prawdopodobnie sekretarz który przedstawił wypowiedź Weila z 14 marca $1913 \mathrm{r}$.

${ }^{41}$ Tamże.

${ }^{42}$ Pierwszy Zjazd Aptekarzy Królestwa Polskiego. „Wiadomości Farmaceutyczne” 1912 s. 233-243 [tu s. 240-241]. 


\section{Badania podstawowe}

Laboratorium miało dwie pracownie: chemiczną oraz bakteriologiczną, w których na zlecenie osób prywatnych i instytucji przeprowadzano podstawowe analizy z zakresu chemii gospodarczej, farmaceutycznej, fizjologicznej, higieny wody, środków spożywczych itp. Na łamach „Wiadomości Farmaceutycznych” ukazywały się ogłoszenia oferujące szeroką gamę analiz:

Pracownia chemiczno-bakteriologiczna TFW przyjmuje rozbiory fizjologiczno-chemiczne, badania chemiczne i bakteriologiczne produktów spożywczych i technicznych, określenie dobroci i czystości towarów oraz przetworów farmaceutycznych, a także przygotowuje płyny mianowane, odczynniki, roztwory barwników itp. ${ }^{43}$

W rocznych sprawozdaniach informowano o działalności podstawowej pracowni. Pierwsze sprawozdanie ukazało się w 1898 r. Ówczesny kierownik pracowni, Białobrzeski, przedstawił w nim zestawienia dotyczące analiz wykonanych od dnia założenia pracowni do 1 stycznia $1898^{44}$. Jak wynika z zestawienia, badań nie było dużo, najwięcej dotyczyło określenia „dobroci” przetworów farmaceutycznych (14) oraz badań moczu (13). Przygotowano również 30 płynów mianowanych i 2 roztwory odczynników. W tym czasie w laboratorium pracowało 10 osób (prawdopodobnie, oprócz stałych pracowników, były to osoby z zewnątrz, którym udostępniono laboratorium do przeprowadzenia własnych badań).

Tabela 1. Analizy przeprowadzone w laboratorium WTF w latach 1897-1901 na podstawie Sprawozdań... ${ }^{45}$.

\begin{tabular}{|l|c|c|c|c|}
\hline Rodzaj badanie & $\mathbf{1 8 9 7}$ & $\mathbf{1 8 9 9}$ & $\mathbf{1 9 0 0}$ & $\mathbf{1 9 0 1}$ \\
\hline Środki spożywcze & 7 & & & 5 \\
\hline Mleko & & 14 & & \\
\hline Wina i lemoniady & 1 & 22 & 17 i 5 & 14 i 6 \\
\hline Woda & 5 & 160 & 30 & 4 \\
\hline Wódka & 4 & & & \\
\hline Analizy fizjologiczne (mocz) & 13 & 275 & 241 & 34 \\
\hline Preparaty farmaceutyczne i specyfiki & 14 & 102 & 15 i 6 & 15 i 8 \\
\hline Środki dezynfekcyjne & 1 & & & \\
\hline Badania sądowe & 3 & & 9 & 1 \\
\hline Rudy i glina & 2 & 93 & 5 & 2 \\
\hline
\end{tabular}

43 Pracownia chemiczno-bakteriologiczna... [Ogłoszenie] „Wiadomości Farmaceutyczne” 1898, s. nienumerowana.

${ }^{44}$ M. Białobrzeski: Sprawozdanie z działalności pracowni chemiczno-bakteriologicznej Towarzystwa farmaceutycznego warsz. „Wiadomości Farmaceutyczne” 1898, s. 47

${ }_{45}$ Tamże, Sprawozdanie z czynności Towarzystwa Farmaceutycznego za 1899-ty rok. „Wiadomości Farmaceutyczne” 1900, s. 97-115; Sprawozdanie z czynności Towarzystwa Farmaceutycznego za 1900-ty rok. „Wiadomości Farmaceutyczne” 1901, s. 96-99. 


\begin{tabular}{|l|c|c|c|c|}
\hline Torf i wapno & & 18 & 10 & 2 \\
\hline Farby & 2 & & & \\
\hline Badania bakteriologiczne & $?$ & $?$ & 29 & 38 \\
\hline Inne & & & 2 & 29 \\
\hline
\end{tabular}

W 1899 r. w pracowni wykonano znacznie więcej analiz: fizjologicznych, farmaceutycznych, wody, win, lemoniady, mleka oraz gliny, rudy, torfu i wapna (razem 840), przygotowano też 156 płynów mianowanych ${ }^{46}$. W następnym roku (pracownia do 1 października 1900 r. kierował Białobrzeski, następnie przejął ją Stępowski) ilość badań fizjologicznych nieco się zmniejszyła, pozostałych badań było znacznie mniej; pojawiły się badania bakteriologiczne, ale ogólna ilość analiz była jednak znacznie mniejsza (366) ${ }^{47}$. W 1901 r. pracownia pozostawała (do dnia 1 kwietnia) pod kierownictwem Stępowskiego, potem prowadził ją Koperski ${ }^{48}$. W tym czasie wykonano mniej badań, wyraźnie zmniejszyła się zwłaszcza liczba badań z zakresu chemii fizjologicznej, które w poprzednich latach były najczęściej wykonywane; nieznacznie wzrosła liczba badań bakteriologicznych, liczba pozostałych analiz utrzymywała się na tym samym poziome lub zmalała. Pojawiły się też nowe produkty do badania, ale nie było ich dużo (nawozy sztuczne - 11; melasa - 9; sok z buraków cukrowych (polaryzacja) - 8). W sumie wykonano tylko 158 analiz, czyli ponad pięć razy mniej niż w 1899 r.

Większość z wyżej wymienionych analiz wykonywano w pracowni chemicznej, wśród nich najczęściej przeprowadzano analizę moczu. Było to jedno z podstawowych badań fizjologicznych, laboratoria posługiwały się jednak różnymi metodami i w różny sposób przedstawiały wyniki. Na posiedzeniu WTF w 1900 r. Stępowski wysunął propozycję ujednolicenia metod i jednolitego sposobu podawania wyników $^{49}$. Zauważył, że od trzech lat, dzięki Białobrzeskiemu, w laboratorium WTF przeprowadzano szczegółową analizę moczu, czyli ilościowe oznaczenie składników, a wyniki podawano jako dane cyfrowe (w innych laboratoriach wyniki były szacunkowe, np. mocznik mały). Zaproponowano wówczas, aby w porozumieniu z Towarzystwem Lekarskim kwestię analizy moczu, coraz ważniejszą dla diagnosty-

${ }^{46}$ Sprawozdanie z czynności Towarzystwa Farmaceutycznego za 1899-ty rok... Ogólna wartość pracowni po potrąceniu 10\% na amortyzację przedstawia sumę 2041 rubli 63 kop. Z pracowni korzystały 23 osoby: 15 farmaceutów, 2 lekarzy, 5 technologów, 1 chemik.

${ }^{47}$ Sprawozdanie z czynności Towarzystwa Farmaceutycznego za 1900-ty rok... Ogólna wartość pracowni po potrąceniu na amortyzacje 1911 rb. kop 42; z pracowni korzystało 15 osób (11 farmaceutów, 1 student chemii, 2 studentki chemii, 1 doktor filozofii).

${ }^{48}$ Sprawozdanie z czynności Towarzystwa Farmaceutycznego za rok 1901-szy... Ogólna wartość po potrąceniu na amortyzację - 1720,28 rb. korzystało z pracowni 8 osób (6 farmaceutów i 2 chemików).

${ }^{49}$ Z. Kłobuszewski: Ósme Ogólne posiedzenie Warszawskiego Towarzystwa Farmaceutycznego. „Wiadomości Farmaceutyczne”1900, s. 482-84. W całym tomie „Wiadomości Farmaceutycznych" z 1900 r. zamieszczano wykłady L. Marchlewskiego o chemii moczu. 
ki lekarskiej, omówić na forum międzynarodowym i dążyć do ujednolicenia metod badawczych oraz wypracowania stałego schematu analizy, który obowiązywałby w całej Europie. Nie wydaje się jednak, aby te plany przyniosły korzyść laboratorium, gdyż wkrótce liczba wykonywanych analiz moczu znacznie zmalała.

Badania bakteriologiczne cieszyły się mniejszym zainteresowaniem, chociaż pracownia była przygotowane na przeprowadzanie podstawowych analiz w tym zakresie. Tuż po uruchomieniu laboratorium na jednym z posiedzeń ogólnych WTF Białobrzeski przedstawił zebranym metody badania „tworu błoniczego”, omówił sposób przygotowania podłoży do hodowli bakterii, sposób zbierania materiału i posiewu oraz najnowsze (stosowane we Wrocławiu) metody barwienia próbek do badań mikroskopowych ${ }^{50}$. W 1898 r. wystąpił z inicjatywą przeprowadzenia prób w kierunku błonicy w pracowni bakteriologicznej WTF. Poinformowano o tym w notatce zamieszczonej w dziale Wiadomości bieżące.

Ostatnio pracowania analityczna przy Towarzystwie Farmaceutycznym rozesłała do wszystkich aptek tzw. przyrządy błonicze służące do bezpośredniego zbierania nalotów gardlanych u chorych budzących podejrzenie błonicy - wiadomo, że często dla postawienia diagnozy nie wystarcza obraz kliniczny, niezbędne jest potwierdzenie bakteriologiczne obecności laseczników Löflera - to skłoniło pracownię do przygotowania odpowiedniego przyrządu ${ }^{51}$.

Przyrząd ów składał się z małego tamponu waty osadzonego na druciku glinowym. Dokładny sposób postępowania dołączony był do każdego przyrządu. Pracownia zapewniała, że jest stale zaopatrywana w odpowiednie podłoże, na którym może prowadzić kulturę bakterii, by każdy lekarz czy nawet opiekun mógł szybko potwierdzić diagnozę. W razie potrzeby interesant posyłał do apteki po przyrząd i po zebraniu materiału kierował go do pracowni. Wyniki otrzymywał po upływie 10-12 godzin w ciągu dnia lub 24 godzin, jeśli materiał do badania przesłano późnym wieczorem. Jakie było zapotrzebowanie na te badania, nie wiadomo, w sprawozdaniach nie zamieszczano żadnych informacji na ten temat, jednak z sumarycznych zestawień wynika, że badania bakteriologiczne nie były często wykonywane.

Już w 1900 r. pracownia przyniosła straty, w 1901 r. deficyt pogłębił się - rozchód przekraczał przychód - brakowało 592 rubli (w tym niedobór za rok poprzedni ${ }^{52}$. W sprawozdaniach z posiedzeń ogólnych, jak i Komitetu WTF nie było jednak wzmianek o trudnej sytuacji finansowej i gwałtownym spadku liczby wykowanych badań. Można przypuszczać, że głównym powodem tych kłopotów była częsta zmiana kierowników i rosnąca konkurencja - w Warszawie powstawały laboratoria

50 [M.] Stypiński: Dziewiąte Ogólne posiedzenie Towarzystwa farmaceutycznego Warszawskiego. „Wiadomości Farmaceutyczne” 1897, s. 546-547.

${ }^{51}$ Wiadomości bieżące. „Wiadomości Farmaceutyczne” 1898, s. 160. Cena za analizę i przyrząd wynosiła 2 ruble.

52 I. Habelski: Pracownia chemiczno-bakteriologiczna przy Warszawskim Towarzystwie Farmaceutycznym za rok 1901. „Wiadomości Farmaceutyczne” 1902, s. 108-109. 
oferujące swoje usługi zarówno w dziedzinie chemii fizjologicznej, jak i badaniach wody oraz środków chemicznych ${ }^{53}$.

W późniejszym okresie w laboratorium WTF wykonywano mniej analiz. W Sprawozdaniu z czynności laboratorium chem. warsz. Tow. Farm ${ }^{54}$ odnotowano, żew 1911 r., a zatem już pod kierownictwem Weila, wykonano zaledwie nieco ponad 50 analiz, wzywano go również do Izby Sądowej w charakterze eksperta. W 1912 r. sytuacja pogorszyła się - wykonano tylko 24 analizy; Weila jako kierownika pracowni powoływano zaś w charakterze doradczym do jednej z fabryk chemicznych. Analiz było jednak bardzo mało, a większości z nich to badania wykonywane nie na zamówienie, ale „dla wyświetlenia kwestii potrzebnej aptekarstwu” - nie przynoszące zatem dochodu. W 1913 r., gdy pracownię prowadził Torżewski, wykonano 126 analiz, większość biologicznych ${ }^{55}$.

\section{Badania nierutynowe}

W laboratorium WTF podejmowano także badania zmierzające do wyjaśnienia istotnych dla aptekarzy kwestii - określenia składu chemicznego surowców i preparatów leczniczych, udoskonalenia metod analitycznych oraz badania zafałszowania leków i żywności ${ }^{56}$. Nie wiadomo, na jakiej zasadzie dokonywano wyboru opracowywanych tematów, wydaje się, że najczęściej badania były podejmowane z inicjatywy kierownika laboratorium, rzadziej na zamówienie, nie przynosiły zatem dochodów, co ograniczało ich zakres. 0 przebiegu i wynikach badań kierownicy laboratorium informowali na łamach „Wiadomości Farmaceutycznych”.

Badania wykonane przez pierwszego kierownika laboratorium - Białobrzeskiego, bądź pod jego nadzorem, dotyczyły kilku zagadnień: składu surowców roślinnych (rdest wężownik, olej Strofantusa), środków leczniczych (preparaty koloidowe Argentum crede i Hyrgolum, woda z gorzkich migdałów), środków pomocniczych w recepturze (Adeps benzoatus), środków spożywczych (masło, pomarańcze), preparatów odżywczych (Somatoza, mączki dla niemowląt), wody (wody studziennej Lublina), przedmiotów codziennego użytku (wyroby gumowe),

${ }^{53}$ W 1906 roku na łamach „Chemika Polskiego” zamieszczono ogłoszenie Pracowni Chemicznej Muzeum Przemysłu i Rolnictwa pod kierunkiem Dra Jana Bieleckiego (Warszawa, Krakowskie Przedmieście 66), która oferowała: Analizy. - Ekspertyzy. - Porady chemiczne. Opracowania metod fabrykacji i patentów. - Dozór chemiczny nad fabrykami. Ponadto w pracowni udostępniano miejsce do pracy dla chemików do badań analitycznych, technicznych i naukowych. Tamże, s. nienumerowana

${ }^{54}$ [S. We il]: Sprawozdanie z czynności laboratorium chem. warsz. Tow. Farm. „Wiadomości Farmaceutyczne" 1913, s. 142-44.

${ }^{55}$ Drugie ogólne posiedzenie Towarzystwa Farmaceutycznego Warszawskiego „Wiadomości Farmaceutyczne" 1914, s. 156-157.

${ }^{56}$ Badania te omówię w osobnym tekście. 
chemii ogólnej ${ }^{57}$. W większości były to prace $\mathrm{z}$ analizy chemicznej i służyły kontroli podejrzanych produktów występujących na rynku warszawskim, ewentualnie odpowiadały na inne nurtujące aptekarzy kwestie.

Stanisław Weil, który objął kierownictwo laboratorium po okresie przestoju w 1909 r., przeprowadził mniej badań; dotyczyły one wykrywania zafałszowań leków i środków spożywczych. Reagując na bieżące potrzeby rynku aptekarskiego, zajął się wykrywaniem najczęściej fałszowanych preparatów leczniczych: Pyramidonu, Santoniny, Siroliny. Pod jego kierunkiem Maria Kwiekówna przeprowadziła badanie Kalium jodatum, sprawdziła również jakość mleka sprzedawanego na rynku warszawskiego, a Stefan Torżewski badał soki owocowe, wody owocowe i gazowane ${ }^{58}$.

\section{Działalność oświatowa}

Od początków istnienia WTF jego członkowie starali się pomagać uczniom i studentom w zdobyciu i rozwijaniu farmaceutycznej wiedzy. W latach 1874-1876 prowadzili odczyty z przedmiotów podstawowych dla farmacji, później odczyty powierzano wykładowcom, opłacając ich ze składek Towarzystwa. W $1891 \mathrm{r}$.

${ }^{57}$ M. Bi ało br zeski : Charakterystyka garbników rdestu-wężownika (Polygonum-bistortae). „Wiadomości Farmaceutyczne” 1899, s. 539-44; tenże: Części składowe tłustego oleju Strofantusa. „Wiadomości Farmaceutyczne” 1901, s. 49-52, 73-75, 113-115; te nże: Kwasy lotne chmielu. „Wiadomości Farmaceutyczne” 1898 s. 286-288; te nż e: Woda z gorzkich migdałów. „Wiadomości Farmaceutyczne” 1897, s. 525-528; te n ż e: Extractum Ferri pomatum. „Wiadomości Farmaceutyczne” 1897, s. 477-479; 501-505; tenże: O zanieczyszczeniach w preparatach koloidalnych. „Wiadomości Farmaceutyczne” 1899, 349-50; tenże: O jełczeniu tłuszczów i racjonalnym przygotowaniu Adeps benzoatus. „Wiadomości Farmaceutyczne” 1899, s. 493-98; te nż e: Somatoza i jej zafałszowanie. „Wiadomości Farmaceutyczne” 1899, s. 423-428; tenże: O nowej metodzie odróżniania masła od margaryny. „Wiadomości Farmaceutyczne" 1897, s. 402-404; tenże, Skład chemiczny niektórych wyrobów gumowych na rynku warszawskim. „Wiadomości Farmaceutyczne”1900, s. 369-73; te nże: Wartość wód miasta Lublina pod względem higienicznym. „Wiadomości Farmaceutyczne” 1901, s. 317-331; 341-345; 367-369; te nże : Dezynfekcyjne własności pastylek. „Wiadomości Farmaceutyczne” 1898, s. 117-122; te nże: Piżmo sztuczne. „Wiadomości Farmaceutyczne” 1897, s. 528530; te nże: O przemianie fosforu $w$ arsen. „Wiadomości Farmaceutyczne” 1900, s. 518-21; M. Białobrzeski, K. Kulesza: Nowe maczki mleczne. „Wiadomości Farmaceutyczne”, 1899, s. 469-71; K. Ku le s za: Z pracowni chemiczno-bakter. W. T. Farmaceutycznego. podat... kilka słów w sprawie sztucznego farbowania pomarańcz. „Wiadomości Farmaceutyczne” 1900, s. 231-32.

${ }^{58}$ S. [S. We il]: O tabletkach santoninowych. „Wiadomości Farmaceutyczne” 1910, s. 11718; S. We il: Zafałszowany «Pyramidon» „Wiadomości Farmaceutyczne” 1909, s. 221; tenże: Dwumetyloamidoantypiryna na rynku warszawskim. „Wiadomości Farmaceutyczne” 1909, s. 237-240; Dr. St. w. [S. We il]: Oznaczanie tiokolu w Sirolinie. „Wiadomości Farmaceutyczne” 1911, s. 353-57. M. Kw i e kó w n a: Kilka słów o jodku potasu. „Wiadomości Farmaceutyczne” 1911, s 257-58; taż: Przyczynek do poznania dobroci mleka, znajdującego się na rynku warszawskim. „Wiadomości Farmaceutyczne” 1910, s. 345-346,. 357-360. S. To r ż e w s ki : Kilka słów o syropach $i$ wodach owocowych i o wodach gazowanych. „Wiadomości Farmaceutyczne” 1913, s. 225-26. 
zrezygnowano z prowadzenia odczytów z powodu coraz mniejszego zainteresowania oraz braku miejsca na prowadzenie zajęć praktycznych, zakładając jednak, że po utworzeniu laboratorium zajęcia zostaną wznowione ${ }^{59}$. Z chwilą otwarcia laboratorium udostępniano je osobom chcącym podnieść swoje kwalifikacje, farmaceutom przygotowującym się do egzaminów. Informowano o tym m.in. w ogłoszeniu zamieszczonym w 1899 r. w „Wiadomościach Farmaceutycznych”.

[...] Panowie farmaceuci pragnący naukowo pracować, mogą praktycznie dopełnić swoje wiadomości z dziedziny analizy chemicznej, analizy moczu, produktów spożywczych i bakteriologii, w pracowni chemiczno-bakteriologicznej Towarzystwa. Zgłaszać się należy do Dyrektora pracowni Magistra farmacji W-go Michała Białobrzeskiego. ${ }^{60}$

Nie wiadomo dokładnie, jakie było zainteresowanie tą propozycją i ilu chętnych się zgłosiło. Skąpe informacje na ten temat można odnaleźć w niektórych sprawozdaniach z działalności laboratorium WTF. Przykładowo, w 1898 r. z pracowni korzystało 19 osób - 14 prowizorów, 4 inżynierów, 1 doktor filozofii, a w 1899 r. - 23 osoby: 15 farmaceutów, 2 lekarzy, 5 technologów, 1 chemik. ${ }^{61}$

W późniejszych latach w laboratorium odbywały się wykłady dla uczniów farmacji pod kierunkiem Aleksandra Bekkera ${ }^{62}$, laboratorium udostępniono również Towarzystwu Kursów Naukowych. Członkowie WTF zauważali też potrzebę szkolenia i uzupełniania wiedzy przez czynnych zawodowo aptekarzy, by uchronić aptekarstwo od grożącego mu regresu. Gdy Weil został kierownikiem laboratorium, wysunął propozycję zorganizowania dla farmaceutów kursu badania żywności.

W początkach XX w. sytuacja aptek w Królestwie Polskim stawała się coraz trudniejsza ${ }^{63}$. Jedną z przyczyn tego stanu rzeczy była rosnąca i nieuczciwa konkurencja. Na łamach prasy zawodowej bardzo często pojawiały się skargi, o nieuczciwe działania oskarżano głównie tzw. składników (drogistów) - właścicieli składów

${ }^{59}$ Zob. Protokół posiedzenia. Siódme Ogólne posiedzenie Towarzystwa farmaceutycznego Warszawskiego. „Wiadomości Farmaceutyczne” 1897, s. 450-475.

${ }^{60}$ Towarzystwo Farmaceutyczne w Warszawie..., [Ogłoszenie],Wiadomości Farmaceutyczne" 1899 s. 223.

${ }^{61}$ Zob. Sprawozdanie z czynności Towarzystwa Farmaceutycznego i kasy Wsparcia za rok 1898. „Wiadomości Farmaceutyczne” 1899, s. 59-66; Sprawozdanie z czynności Towarzystwa Farmaceutycznego za 1899-ty rok. „Wiadomości Farmaceutyczne” 1900, s. 97-115 (tu s. 98).

${ }^{62}$ Sprawozdanie z czynności Warszawskiego Towarzystw Farmaceutycznego za rok 1903-ci. „Wiadomości Farmaceutyczne” 1904, s. 37-67. Po odbyciu kursów 30 uczniów przystąpiło do egzaminu na stopień pomocnika aptekarskiego (s. 38).

${ }^{63}$ E. Chrzan owski : Stan aptekarstwa w Państwie Rosyjskim. Odczyt wygłoszony przez... na X Zjeździe przyrodników i lekarzy polskich we Lwowie. „Wiadomości Farmaceutyczne” 1908, s. 24-26; 40-44; 53-55. Zob. też E. Wi ę c ko ws ka: Pracownicy apteczni w Królestwie Polskim na przełomie XIX i XX wieku. [w:] Zawód Farmaceuty na ziemiach polskich w XIX i XX wieku. Pod red. B. Ur b a n ek, Warszawa - Katowice 2006, s.105-116. 
aptecznych i chemicznych, którzy mieli wprawdzie ograniczone prawa do sprzedaży i wyrobu środków leczniczych, ale w praktyce prawo to nie zawsze było przez nich respektowane. Wymagania stawiane drogistom przy otwarcia i prowadzenia składów nie były też tak obciążające jak w przypadku aptek, dlatego sprzedawane w składach środki lecznicze były tańsze od aptecznych, nie zawsze jednak odpowiedniej jakości. Niepokojąca była także kwestia otwierania nowych aptek i konkurencja między aptekami starymi i nowopowstającymi. Obawiano się zwłaszcza konkurencji Żydów, którzy, posiadając inne źródła utrzymania, przyjmowali koncesje nawet tam, gdzie było to nieopłacalne, ponieważ praca w aptece dawała im prawo do osiedlania się na terenie całej Rosji i Królestwa.

Problem nadmiernej liczby aptek, a co za tym idzie ostrej konkurencji, nasilił się po zmianach w ustawodawstwie dotyczących otwierania nowych aptek, pozwalających na otwieranie aptek przez tzw. ziemstwa ${ }^{64}$. Prowadziło to do zubożenia i niepewnej sytuacji finansowej aptekarzy, a w konsekwencji do niezadowolenia i strajków pracowników aptecznych (1905-1906), którzy domagali się polepszenia warunków pracy i lepszych wynagrodzeń. Sytuacja nie sprzyjała także podnoszeniu kwalifikacji zawodowych, i mimo że nad wykształceniem farmaceutów toczyła się nieustanna dyskusja, pojawiły się głosy, że zawód ten nie jest atrakcyjny, by przyciągnąć zdolną młodzież, nie można więc zbyt wiele wymagać od kandydatów na uczniów. Wszystko to wpływało na mierną ocenę stanu aptekarstwa w oczach społeczeństwa.

Weil uważał, że część winy za tę sytuację leży po stronie aptekarzy, krytykował ich za „braki w wykształceniu, bierność moralną i nieumiejętność czynu o szerszym rozmachu"65. W 1910 r., podczas posiedzenie WTF, wystąpił z referatem: Nasze zdania, w którym wypowiedział się m.in. o roli, jaką pracownie chemiczne powinny pełnić dla poprawy stanu aptekarstwa. Przedstawiając sytuację w Królestwie Polskim, wyraził swój niepokój i stwierdził, że zawód aptekarza, kiedyś cieszący się powszechnym poważaniem, utracił społeczne zaufanie, a aptekarzy uważa się za wyzyskiwaczy, grupę ludzi nieproduktywnych i nieużytecznych. Apteki są traktowane na równi ze składami aptecznymi, a nawet składy uważane są za lepsze od aptek,

${ }^{64}$ Chrzanowski twierdził, że zła jakość usług w aptekach, punktach szpitalnych, ambulatoriach zakładanych przez ziemstwa, wynika z faktu, że przygotowaniem lekarstw w tych punktach zajmowali się felczerzy lub siostry miłosierdzia, a nawet chłopcy nie będący uczniami, czasem zaś uczniowie; w najlepszym przypadku podaptekarz czy prowizor był zarządzającym, ale przygotowywaniu leków nie poświęcał zbyt wiele uwagi, gdyż zajmował się głównie rachunkowością (uwaga nie pozbawiona złośliwości - autor sugerował, że najważniejszym zadaniem aptekarza w takich aptekach jest skalkulowanie recept najtańszym kosztem). Zob. Te nż e : Stan aptekarstwa... Projekt ustawy aptekarskiej przedstawiony był i komentowany na łamach „Wiadomości Farmaceutycznych” w 1912.

${ }^{65}$ S. W eil: Nasze zadania... s. 168-72. Jest to skrót odczytu wygłoszonego na posiedzeniu WTF z 11 marca $1910 \mathrm{r}$. 
bo oferują tańszy towar - „dalej tak bieg życia farmaceutów płynąć nie może” - zauważał'6.

Proponował zatem podjęcie działań niezbędnych do podniesienia poziomu aptekarstwa i wskazywał na potrzebę nowego pola działania, dzięki któremu aptekarze mogliby pokazać swoją użyteczność. Według niego jednym z podstawowych zadań laboratorium WTF powinna stać się praca na polu czysto naukowym, np. synteza nowych środków leczniczych, oparta na teorii i fizjologicznych badaniach, a także prace nad wyjaśnieniem budowy alkaloidów i innych związków czynnych występujących w surowcach leczniczych, oraz praca nad przyrządami czy preparatami leczniczymi. Na polepszenie sytuacji aptekarzy mogła wpłynąć też produkcja przetworów chemicznych i chemiczno-farmaceutycznych (fotograficznych, perfumeryjnych). Laboratorium WTF powinno dążyć do opracowania metod produkcji tych środków na niewielką skalę, możliwych do podjęcia w aptekach ${ }^{67}$. Te śmiałe plany nie doczekały się jednak realizacji.

Weil zwrócił też uwagę na niewykorzystaną przez farmaceutów dziedzinę analizę środków spożywczych. Widział w niej jeden z istotnych kierunków rozwoju zawodowej działalności, dzięki której apteki przekształciłyby się w instytucje sanitarne oparte na nauce, które społeczeństwo będzie odróżniać od składu - „sklepiku". Taka działalność, jego zdaniem, powinna wpłynąć na odbudowę zawodowego prestiżu i zaufania, a jednocześnie przynosić dochody (analizy byłyby płatne rocznie przez samorząd miejski, gminę czy instytucję publiczną lub osoby prywatne). Zachęcał do tworzenie w miastach i miasteczkach laboratoriów - stacji doświadczalno-higienicznych pod zarządem farmaceutów. Powołując się na przykłady z Europy Zachodniej zaznaczał, że tam przydatność laboratoriów i kontrola jakości środków spożywczych jest rzeczą niepodlegającą dyskusji, i są na to przeznaczane odpowiednie środki (np. Kraków wydawał na ten cel 70000 koron rocznie). Jednak, aby laboratoria mogły powstać i funkcjonować, farmaceuci muszą być przeszkoleni w analizie środków spożywczych. Wystąpił więc z propozycją, aby w dużych miastach, (np. w Warszawie) organizować miesięczne lub sześciotygodniowe kursy badania środków spożywczych a jednocześnie prowadzić akcję uświadamiającą społeczeństwo o konieczności kontroli żywności (odczyty), a także zyskać poparcie instytucji publicznych $^{68}$.

Tworzenie laboratoriów przyaptecznych, w których badano by środki spożywcze, nie był nowym pomysłem; z podobną propozycją członkowie Towarzystwa występowali wcześniej, m.in. Alfons Bukowski i Bronisław Koskowski. Weil propono-

${ }^{66}$ Tamże.

${ }^{67}$ Zdaniem Weila, aptekarze mogliby także podjąć się uprawy roślin lekarskich - stworzenia krajowych plantacji, ograniczenia przywozu surowców zza granicy, poprawy wydajności roślin, zwiększenie zawartości substancji czynnych, uszlachetnianie odmian - przyniosłoby to korzyść dla społeczeństwa i nauki. Tamże.

${ }^{68}$ Tamże. 
wał jednak, aby Towarzystwo służyło aptekarzom pomocą w zdobyciu niezbędnej wiedzy i umiejętności - posiadało bowiem laboratorium, zbiory i bibliotekę oraz niezbędny sprzęt do badań bakteriologicznych. Właściciele aptek, którzy chcieliby założyć stację do badań środków spożywczych w miastach prowincjonalnych, powinni znaleźć pomoc i wsparcie w laboratorium WTF $^{69}$.

Propozycja Weila spotkała się z poparciem członków Towarzystwa, Koskowski podkreślał, że laboratorium WTF powinno stać się wzorem dla doświadczalnych stacji w miastach prowincjonalnych. Zgłoszono również pomysł zorganizowania wykładów dla farmaceutów, dotyczących badania żywności ${ }^{70}$.

Do sprawy laboratorium i badania środków spożywczych Weil powrócił rok później w referacie Ważne zadanie ${ }^{71}$, w którym po raz kolejny zwrócił uwagę na potrzebę nadania aptekarstwu bardziej naukowego charakteru. Uważał, że apteki, tak jak na zachodzie Europy, powinny pełnić funkcje o znaczeniu kulturalno-społecznym. Farmaceuci, jego zdaniem, powinni rozszerzyć swoją działalność na kwestie sanitarne i zdrowotności publicznej. Uważał, że należy stworzyć sieć stacji badających żywność, by w ten sposób stać się instytucją kontroli sanitarnej, zyskując przy tym poważanie, a także dochody. Farmaceuta miał stać się „stróżem higieny wśród ludności okolicznej”, którego zadaniem byłoby zapobieganie chorobom „krzewienie samowiedzy higieniczno-społecznej”. Weil powtórzył też propozycję zorganizowania kursu badania środków żywności oraz popularnych odczytów uświadamiających o konieczności kontroli środków spożywczych (ilustrowanych diapozytywami i doświadczeniami). Odczyty o znaczeniu dydaktyczno-kulturalnym sprzyjałyby rozwojowi racjonalnego handlu i przemysłu oraz kształceniu społeczeństwa - podniesieniu higienicznej świadomości. Tematy miały dotyczyć np. zdrowotności wody do picia (z pokazem bakteriologicznym i chemicznym), zafałszowania mleka (sposoby wykrycia, demonstracje, obliczenie strat materialnych ponoszonych przez ludność wskutek spożywania mleka rozcieńczonego lub zafałszowanego). Uświadamianie korzyści płynących z kontroli środków spożywczych miało być zadaniem nowo powstających przy aptekach pracowni analitycznych i przyczyniać się do podniesienia zdrowotności rejonu. Towarzystwa farmaceutyczne w Warszawie, Zagłębiu, Łodzi, Siedlcach miały zająć się opracowaniem tekstu odczytu, przygotowaniem ilustracji i przezroczy, „latarni”, odczynników, etc. - w ten sposób skompletowane tematy opakowane w odpowiednie skrzyneczki miały oczekiwać na prelegenta. Towarzystwo lub sam prelegent powinni też zająć się organizacją odczytu - pozwoleniem władz, salą, reklamą, biletami

\footnotetext{
${ }^{69}$ Trzecie Ogólne posiedzenie Warszawskiego Towarzystwa Farmaceutycznego. „Wiadomości Farmaceutyczne” 1910, s. 152-158; uwagi dotyczące laboratorium zob. s.153-154.

${ }^{70}$ Tamże, s. 153-154.

${ }^{71} \mathrm{St}$. W. [Weil]: Pod adresem towarzystw farmaceutycznych i ogółu farmaceutów. WAŻNE ZADANIE „Wiadomości Farmaceutyczne” 1911, s. 385-387.
} 
(po 3-5 kopiejek). „Sprawa ta nie powinna trafić ad acta, lecz rozpalić mózgi ogółowi farmaceutów i zostać wprawiona w czyn" - apelował Weil ${ }^{72}$.

\section{Kursy badania żywności}

Mimo pozytywnego przyjęcia przez członków Towarzystwa propozycji Weila, sprawa zorganizowania kursów przeciągała się. Rok po przyjęciu jego wniosku, na łamach „Wiadomości Farmaceutyczne” ukazała się notatka, przypominająca o tej sprawie $^{73}$. Po raz kolejny zauważano, że w Europie Zachodniej kształci się specjalistów - chemików środków spożywczych, jednak u nas i w Rosji wciąż takich specjalistów brak, a potrzeby są coraz większe. W aptekach podwaliny pracowni już są, jest lokal i znaczna część odczynników; potrzeba jednak odpowiedniego wyszkolenia pracowników, gdyż w uniwersytetach rosyjskich nie uczono badania żywności. W tym celu - informowano w notatce - WTF planuje od 1 do 31 maja 1911 r. zorganizowanie przy pracowni chemicznej kursu badania żywności. Organizatorzy zapowiadali, że główny nacisk będzie położony na stronę praktyczną badań - pracę w laboratorium; zajęcia i wykłady będą prowadzone przez miesiąc, aby przybyłym z prowincji w jak najkrótszym czasie przekazać najwięcej wiadomości fachowych i praktycznych. Opłata za cały kurs miała wynosić 40 rubli, a ilość miejsc była ograniczona.

Niedługo po ogłoszeniu ukazała się kolejna entuzjastycznie brzmiąca notatka A więc rozpoczynamy... ${ }^{74}$. Autor powtórzył informacje o zorganizowaniu kursu, dodając: „stawiamy pierwsze kroki na drodze, która doprowadzi do rzucenia na cały kraj pracowni badania środków spożywczych"75. Informował, że podczas wykładów słuchacze zapoznają się z podstawowymi wiadomościami dotyczącymi składu środków spożywczych, ich właściwości, najczęściej spotykanych zafałszowań i sposobów ich wykrywania. Słuchacze mieli również poznać wymogi prawne, jakie stawiają środkom spożywczym różne państwa Europy, a na zajęciach praktycznych poznać najważniejsze metody badania oraz potrzebne do badań przyrządy. Zajęcia miały trwać cały dzień od godziny 9:00 do 13:00 i od 15:00 do 19:00.

Propozycja spotkała się z dużym zainteresowaniem, kurs został jednak przełożony na bardziej dogodny termin - na październik, a w końcu na listopad ${ }^{76}$. Nadal entuzjastycznie przedstawiano zadania nowoczesnego farmaceuty, który nie może ograniczać swojej działalności do ekspedycji gotowych leków i do zanikającej

${ }^{72}$ Tamże.

${ }^{73}$ Notatka. „Wiadomości Farmaceutyczne” 1911, s. 97-99.

${ }^{74}$ M. A więc rozpoczynamy.... „Wiadomości Farmaceutyczne” 1911, s. $114-115$.

${ }^{75}$ Tamże.

${ }^{76}$ Komitet WTF postanowił przesunąć kurs na jesień z powodu nieobecności w Warszawie kierownika laboratorium. Od redakcji. „Wiadomości Farmaceutyczne” 1911, s. 149, 169. Zob. też S. [S. We i l?]: Praktyczny kurs badania środków spożywczych „Wiadomości Farmaceutyczne" 1911, s. 369-370. 
czynności preparowania leków: „życie wymaga od nas czegoś więcej, wymaga zarówno interes społeczny, jak i nasz własny materialny i moralny, farmaceuta doby współczesnej powinien dążyć do tego, aby w społeczeństwie odegrać rolę opiekuna zdrowotności rejonu, w którym pracuje"77. Farmaceuta miał stać się współpracownikiem lekarza, zajmując się tym działem pracy, który z natury rzeczy wymyka się spod kompetencji lekarza, a jednym z ważniejszych zadań była kontrola żywności i analiza wody do picia. Piecza nad tą sprawą powinna znajdować się w rękach farmaceutów, dodawał autor (Weil?), którzy rozrzuceni po całym kraju mogą tę prace podjąć w szerokim zakresie.

Kolejne informacje o kursie znalazły się w Sprawozdanie z działalności Warsz. Tow. Farmaceutycznego za rok $1911^{18}$, w którym stwierdzono jedynie, że kurs napotkał trudności nieprzewidziane i niezależne od Towarzystwa. Specjalne zajęcia laboratoryjne zostały przeprowadzone pod kierunkiem Weila, stosownie do dyrektywy nakreślonej przez Towarzystwo. Na podstawie tych szczątkowych informacji trudno stwierdzić, jak rzeczywiście wyglądał kurs, ile osób wzięło w nim udział i na czym polegały wspomniane trudności.

\section{Podsumowanie}

W 1912 r., z okazji z okazji 40-lecia WTF, na łamach „Wiadomości Farmaceutycznych" ukazał się okolicznościowy tekst, w którym 15-letnią działalność laboratorium uznano za niewystarczającą

[...] nie doszła do skali, jakiej chcieliby ją mieć inicjatorzy tej placówki naukowo-kulturalnej mającej podnieść umysłowość naszego ogółu aptekarskiego - do tego potrzebne są fundusze i w tym celu zostało zapoczątkowane zbieranie Żelaznego Funduszu Laboratoryjnego ${ }^{79}$.

Można przypuszczać, że autor tekstu, wieloletni sekretarz WTF - Wincenty Borejsza, wyraził nie tylko własną opinię, ale i pozostałych członków, a krytyczna ocena dotyczyła głównie okresów przestoju (1902-1909), gdy laboratorium nie pełniło swojej funkcji lub gdy było dzierżawione i wykonywano w nim jedynie prace usługowe (1901-1902; 1913-1914).

Należy zauważyć, że mimo przestoju i problemów finansowych, w laboratorium wykonano wiele badań dających odpowiedź na ważne dla aptekarzy pytania, a omawianie tych badań w „Wiadomościach Farmaceutycznych” umożliwiało poznanie metod analitycznych oraz skłaniało do dyskusji środowisko

${ }^{77}$ Tamże.

${ }^{78}$ Sprawozdanie z działalności Warsz. Tow. Farmaceutycznego za rok 1911 „Wiadomości Farmaceutyczne" 1912 s. 19-21.

${ }^{79}$ W. B o r e j s z a : Czterdziestolecie.... Wincenty Borejsza pełnił wówczas funkcję sekretarza WTF. 
aptekarskie Królestwa Polskiego. Na działalność badawczą największy wpływ mieli kierownicy. Białobrzeski i Weil starali się uwzględniać aktualne problemy, z którymi stykali się aptekarze. Weila wyraźnie określił, jakie zdania powinno spełnić laboratorium WTF - o czym pisał w tekście Nasze zadanie - powinno służyć aptekarzom i społeczeństwu, sprawować kontrolę nad jakością leków i środków spożywczych.

Działalność oświatowa początkowo była skierowana na szkolenia młodzieży farmaceutycznej. Od początku istnienia WTF było to jednym z jego głównych zadań, a otworzenie laboratorium stworzyło możliwość praktycznego szkolenia i doszkalania młodych aptekarzy, w mniejszym zaś stopniu innych osób zainteresowanych badaniami. Z informacji zamieszczanych w „Wiadomościach Farmaceutycznych" można uznać, że w pierwszych latach po otwarciu laboratorium szkolenia cieszyły się zainteresowaniem, w późniejszym okresie chętnych było coraz mniej. WTF dostrzegało też potrzebę doszkalania aptekarzy, ciągłego doskonalenia zawodowej wiedzy. Szkolenie pracujących farmaceutów miało dać im możliwość rozwoju, zdobycia nowych umiejętności, a wreszcie podnoszenia prestiżu zawodu. Kurs badania żywności miał być odpowiedzią na te potrzeby. Laboratorium dawało też możliwość (w niewielkim stopniu) pracy naukowej, poszukiwania nowych metod badawczych, nowych leków. Te ambitne plany zostały jednak zrealizowane w niewielkim stopniu.

Różne przyczyny - problemy finansowe i nieporozumienia między członkami Towarzystwa oraz niestabilna sytuacja aptekarstwa - złożyły się na to, że zorganizowane z dużym wysiłkiem i kosztem wieloletnich składek oraz darów członków WTF laboratorium nie zostało w pełni wykorzystane i mimo wysiłków kierujących nim osób, nie spełniło roli, jaką mu wyznaczono. Tylko w latach, gdy było czynne na normalnych warunkach (1897-1900 i 1909-1912), przeprowadzone w nim badania miały charakter wzorcowy i opiniotwórczy, wskazywały także kierunki rozwoju aptekarskiej wiedzy i konieczność stałego podnoszenia zawodowych umiejętności. 


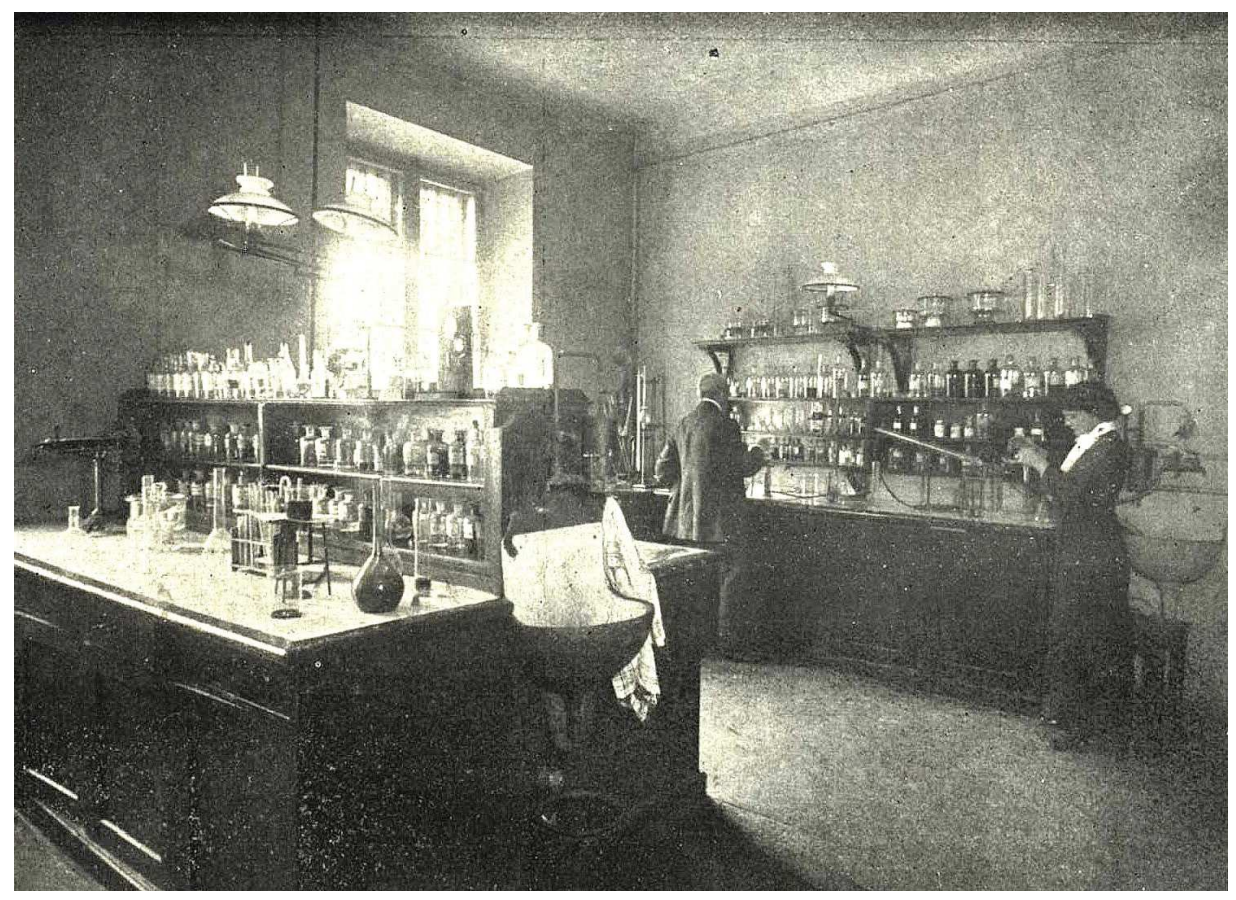

Il. 1. Laboratorium analityczne WTF

Zdjęcia pochodzą z tomu „Wiadomości Farmaceutyczne” 1912.

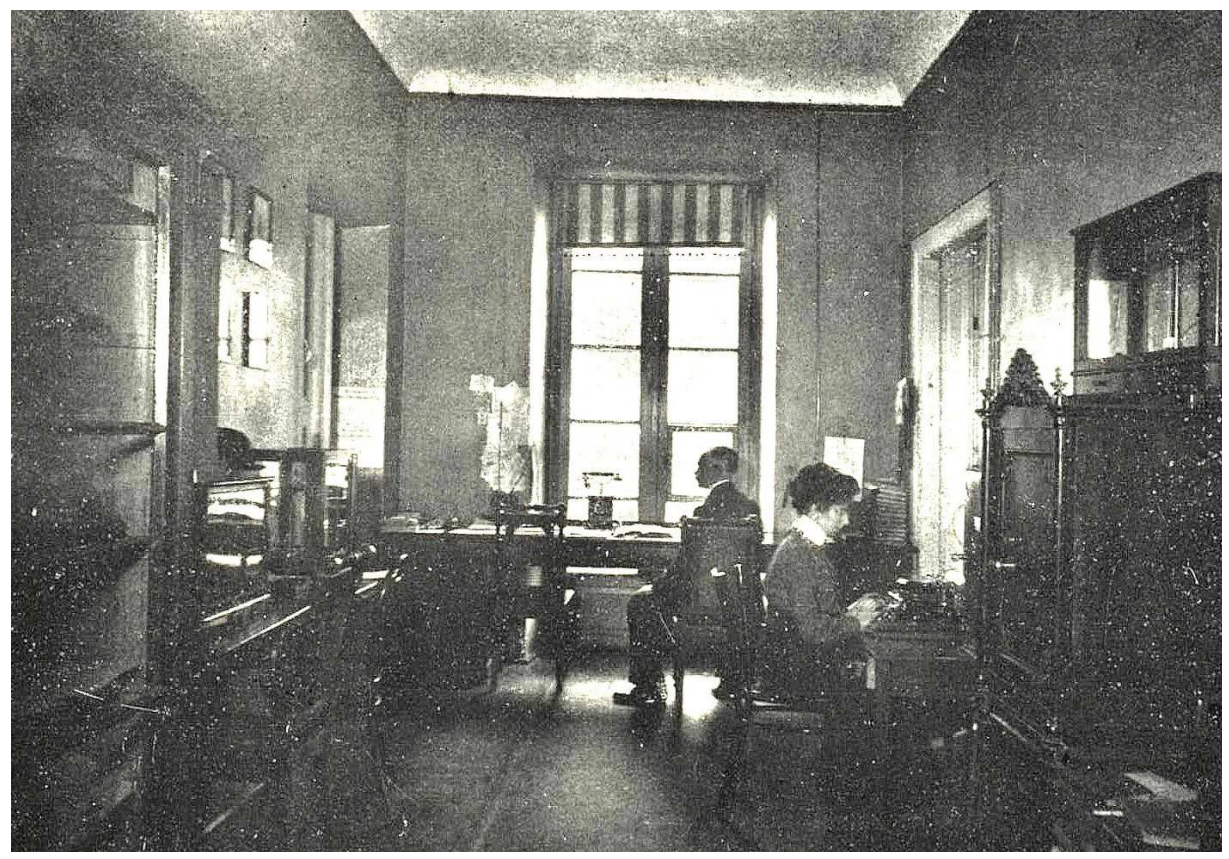

Il. 2. Sala wagowa i pokój sekretarza 


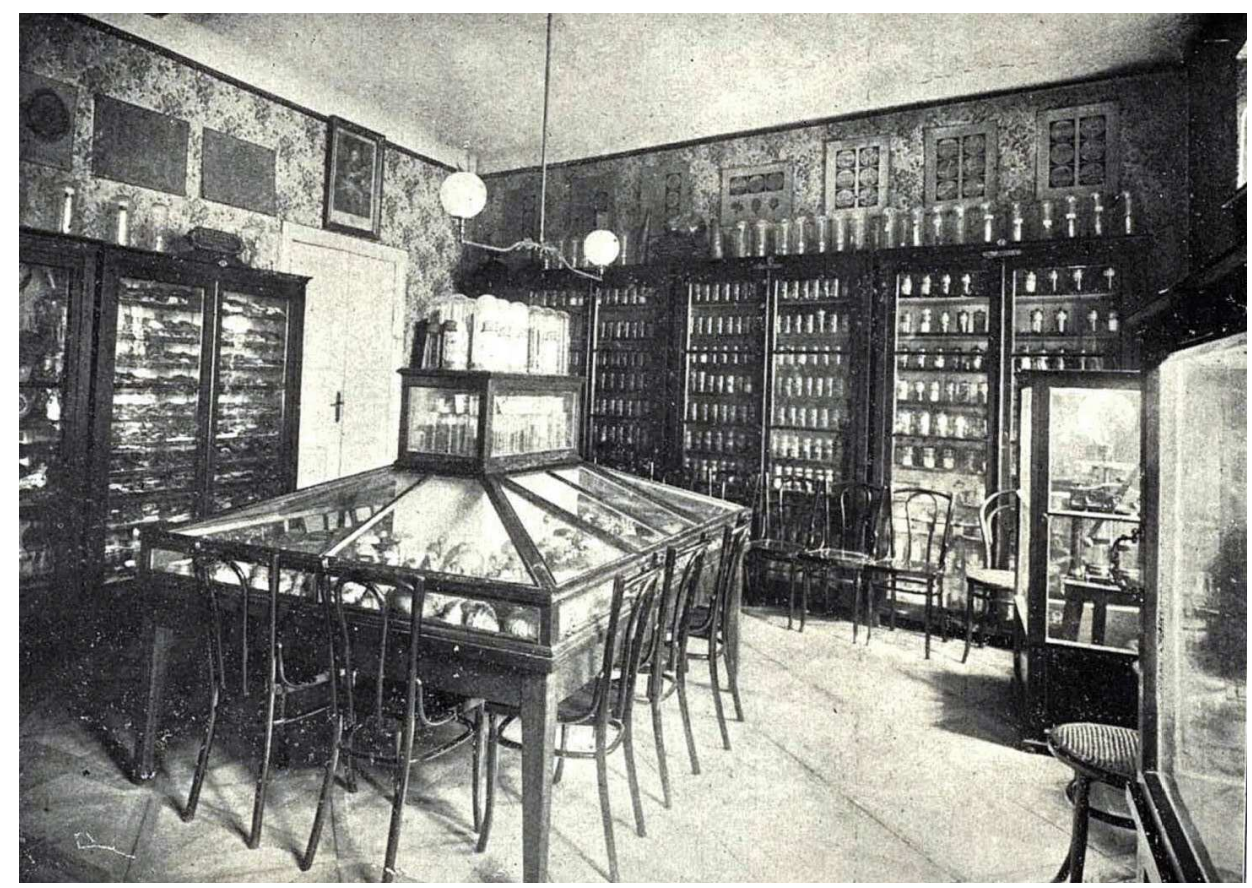

I1.3 3. Sala zbiorów

\section{LITERATURA}

M. Białobrzeski: Sprawozdanie z działalności pracowni chemiczno-bakteriologicznej Towarzystwa farmaceutycznego warsz. „Wiadomości Farmaceutyczne” 1898, s. 47.

H. Bi ertüm pfel: Odezwa w sprawie Pracowni Chemiczno-rozbiorowej przy Warszawskim Towarzystwie Farmaceutycznym. „Wiadomości Farmaceutyczne” 1914, s. 273-275.

H. Bi ertüm pfel, J. F. Ku śmi er ski: Jeszcze kilka słów w sprawie pracowni chemiczno-rozbiorowej. „Wiadomości Farmaceutyczne” 1902, s. 431-432.

W. Borejsza: Czterdziestolecie Warszawskiego Towarzystwa Farmaceutycznego. „Wiadomości Farmaceutyczne" 1912, s. 405-17.

J. Brzezińska: Rola Uniwersytetu w Dorpacie w kształceniu polskich studentów farmacji 1802-1918, Kołobrzeg 2017.

A. Bukow ski: [bez tytułu] „Wiadomości Farmaceutyczne” 1901, s. 312-313

E. Chrzanowski: Stan aptekarstwa w Państwie Rosyjskim. Odczyt wygłoszony przez... na X Zjeździe przyrodników i lekarzy polskich we Lwowie. „Wiadomości Farmaceutyczne” 1908, s. 24-26; 40-44; 53-55.

Dzieje nauki farmaceutycznych $w$ Polsce 1918-1978. Pod red. Z. Jerzmanowskiej i B. Kuźnickiej, Warszawa-Łódź 1986.

A. Dan ek: Leksykon farmacji, Warszawa 1990. 
Drugie ogólne posiedzenie Towarzystwa Farmaceutycznego Warszawskiego „Wiadomości Farmaceutyczne" 1914, s. 156-157.

[I.] Habelski: Pracownia chemiczno-bakteriologiczna przy Warszawskim Towarzystwie Farmaceutycznym za rok 1899. „Wiadomości Farmaceutyczne” 1900, s.112-113.

[I.] Habelski: Pracownia chemiczno-bakteriologiczna przy Warszawskim Towarzystwie Farmaceutycznym za rok 1901. „Wiadomości Farmaceutyczne” 1902, s. 108-109.

[W. Karpiński]: Odpowiedź na artykuł zamieszczony w No 11 »Wiadomości Farmaceutycznych « pod tytułem »W imię prawdy i dobra Towarzystwa« „Wiadomości Farmaceutyczne” 1901, s. 311-312.

T. Kikta: Przemysł farmaceutyczny w Polsce. Warszawa 1972, PZWL.

Z. Kłobuszewski: Ósme Ogólne posiedzenie Warszawskiego Towarzystwa Farmaceutycznego. „Wiadomości Farmaceutyczne” 1900, s. 482-84.

Z. Kłobus ze wski: Pierwsze Ogólne posiedzenie Warszawskiego Towarzystwa Farmaceutycznego. „Wiadomości Farmaceutyczne” 1901, s. 67-68.

Z. Kłobuszewski: Siódme Ogólne posiedzenie Warszawskiego Towarzystwa Farmaceutycznego. „Wiadomości Farmaceutyczne” 1902, s. 410-411.

Z. Kło bus ze wski: Szóste Ogólne posiedzenie Warszawskiego Towarzystwa farmaceutycznego. „Wiadomości Farmaceutyczne” 1901, s. 335-36.

Z. Kło bus ze ws ki: Szóste Ogólne posiedzenie Warszawskiego Towarzystwa Farmaceutycznego. „Wiadomości Farmaceutyczne” 1902, s. 288-290.

Komitet W.T.F.: W imię prawdy i dobra Towarzystwa naszego „Wiadomości Farmaceutyczne" 1901, s. 279-281.

M.: A więc rozpoczynamy..., „Wiadomości Farmaceutyczne” 1911, s. 114-115.

Notatka. „Wiadomości Farmaceutyczne” 1911, s. 97-99.

Nowo otworzona Pracownia Chemiczno-analityczna przy Towarzystwie Farmaceutycznym w Warszawskie „Wiadomości Farmaceutyczne” 1897, s. 474-475.

Obchody 60-lecia istnienia Warszawskiego Towarzystwa farmaceutycznego. „Wiadomości Farmaceutyczne"1933, s. 18-24, 45-47.

Pierwszy Zjazd Aptekarzy Królestwa Polskiego. „Wiadomości Farmaceutyczne” 1912, s. 233-43.

Posiedzenie Komitetu warsz. Tow. Farmaceutycznego. „Wiadomości Farmaceutyczne” 1913 s. 131.

Pracownia chemiczno-bakteriologiczna... [ogłoszenie] „Wiadomości Farmaceutyczne” 1898, s. nienumerowana.

Pracownia chemiczno... [ogłoszenie]. „Wiadomości Farmaceutyczne” 1901 nr 20 s. nienumerowana.

Pracownia Chemiczna Muzeum... [ogłoszenie], „Chemik Polski” 1906, s. nienumerowane.

Pracownia Chemiczno-Rozbiorowa... [ogłoszenie]. „Wiadomości Farmaceutyczne” $1904 \mathrm{nr}$ Protokół posiedzenia. Siódme Ogólne posiedzenie Towarzystwa farmaceutycznego Warszawskiego. „Wiadomości Farmaceutyczne” 1897, s. 446-475.

Sprawozdanie z czynności Warszawskiego Towarzystw Farmaceutycznego za rok 1903-ci. „Wiadomości Farmaceutyczne” 1904, s. 37-67,

Sprawozdanie z czynności Warszawskiego Towarzystwa farmaceutycznego za rok 1904. „Wiadomości Farmaceutyczne” 1905, s. 43-44. 
Sprawozdanie z czynności Towarzystwa Farmaceutycznego i kasy Wsparcia za rok 1898. „Wiadomości Farmaceutyczne” 1899, s. 59-66.

Sprawozdanie z czynności Towarzystwa Farmaceutycznego za 1899-ty rok. „Wiadomości Farmaceutyczne"1900, s. 97-115.

Sprawozdanie z czynności Towarzystwa Farmaceutycznego za 1900-ty rok. „Wiadomości Farmaceutyczne" 1901, s. 96-99.

Sprawozdanie z czynności Towarzystwa Farmaceutycznego za rok 1901-szy. „Wiadomości Farmaceutyczne" 1902, s. 95-97.

Sprawozdanie z czynności Warszawskiego Towarzystw Farmaceutycznego za rok 1903-ci. „Wiadomości Farmaceutyczne” 1904, s. 37-67.

Sprawozdanie z czynności Warszawskiego Towarzystwa Farmaceutycznego za rok 1905. „Wiadomości Farmaceutyczne” 1906, s. 3-5.

Sprawozdanie z działalności warsz. Tow. Farmaceutycznego za rok 1907. „Wiadomości Farmaceutyczne"1908, s. 1-3.

Sprawozdanie z działalności warsz. Tow. Farmaceutycznego za rok 1909. „Wiadomości Farmaceutyczne" 1910, s. 21-23.

Sprawozdanie z działalności Warsz. Tow. Farmaceutycznego za rok 1911. „Wiadomości Farmaceutyczne" 1912, s. 19-21.

[M.] Stypiński: Dziewiq̨te Ogólne posiedzenie Towarzystwa farmaceutycznego Warszawskiego. „Wiadomości Farmaceutyczne” 1897 s. 546-547.

[M.] Sty piń s ki: Piąte Ogólne posiedzenie Towarzystwa farmaceutycznego Warszawskiego. „Wiadomości Farmaceutyczne” 1897, s. 254-255.

Szóste Ogólne Posiedzenie Towarzystwa farmaceutycznego Warszawskiego. „Wiadomości Farmaceutyczne"1899, s. 291-293.

Szóste Ogólne posiedzenie Warszawskiego Towarzystwa Farmaceutycznego. „Wiadomości Farmaceutyczne" 1909, s. 259-260.

Szóste Ogólne posiedzenie Warsz. Tow. Farmaceutycznego. „Wiadomości Farmaceutyczne” 1911, s. 405-408.

Trzecie Ogólne posiedzenie Warszawskiego Towarzystwa Farmaceutycznego. „Wiadomości Farmaceutyczne" 1910, s. 152-158.

Trzecie ogólne posiedzenie Warszawskiego Towarzystwa Farmaceutycznego. „Wiadomości Farmaceutyczne" 1913, s. 221-22.

Warszawskie Towarzystwo Farmaceutyczne oraz Instytucje Pokrewne i z inicjatywy T-wa powstałe w perspektywie 1859-1834, Warszawa 1934 (dodatek do WF).

S. [S. Weil?]: Praktyczny kurs badania środków spożywczych. „Wiadomości Farmaceutyczne" 1911, s. 369-370.

St. W. [Weil]: Pod adresem towarzystw farmaceutycznych i ogółu farmaceutów. WAŻNE ZADANIE. „Wiadomości Farmaceutyczne” 1911, s. 385-387.

S. Weil: Nasze zadania. „Wiadomości Farmaceutyczne” 1910, 168-72.

[S. Weil]: Sprawozdanie z czynności laboratorium chem. warsz. Tow. Farm.. „Wiadomości Farmaceutyczne" 1913, s. 142-44.

Wiadomości bieżące. „Wiadomości Farmaceutyczne” 1898, s. 160.

E. Wię ckows ka: Pracownicy apteczni w Królestwie Polskim na przełomie XIX i XX wieku. [w:] Zawód Farmaceuty na ziemiach polskich w XIX i XX wieku, pod red. B. Urbanek, Warszawa - Katowice 2006, s.105-116. 